\title{
Between Pragmatism and Order: Medical Organization and Daily Routine
}

The following introduction to hospital life and services outlines changes and continuities and presents the various actors involved. The mid-1930s, by which time the hospital had cast off its provisional character, and the mid-196os, when it again expanded considerably after Gabonese independence, serve as the two major points of reference. The spatial organization, the structural hierarchy, and the development of infrastructure illustrate how the Albert Schweitzer Hospital reflects trends and concerns of other health institutions on the continent. A precise comparison is often difficult as these matters varied greatly in different African hospitals, which, moreover, have usually left behind much less detailed documentation.

The hospital authorities attempted to maintain an underlying order, but staff and patients alike approached their stay with a pragmatic attitude. The former had very broad responsibilities, while the latter embedded treatment at the hospital within their conceptions of health and therapeutic practices. This balancing act between order and pragmatism is also a striking feature of the specific medical practices to be analyzed in the chapters that follow. It will thus be insightful to begin by considering the extent to which these principles underlay the hospital's organization and routine.

The hospital's development can be divided into four phases, with the first occurring from 1913-1917..$^{1}$ One and a half years before the outbreak of World War One, Schweitzer and his wife Helene, who served as a nurse, arrived on the grounds of the Paris Evangelical Missionary Society on the Ogooué River. The story goes that they started to practice in what had been a chicken coop (see Illustration 1). After four months, they had a building constructed with a concrete foundation and a ribbed roof. It had two rooms and served as a consultation space and pharmacy, as well as a sterilization and storage unit. In addition,

1 Mabika, 'L'hôpital Albert Schweitzer de Lambaréné', 202. 


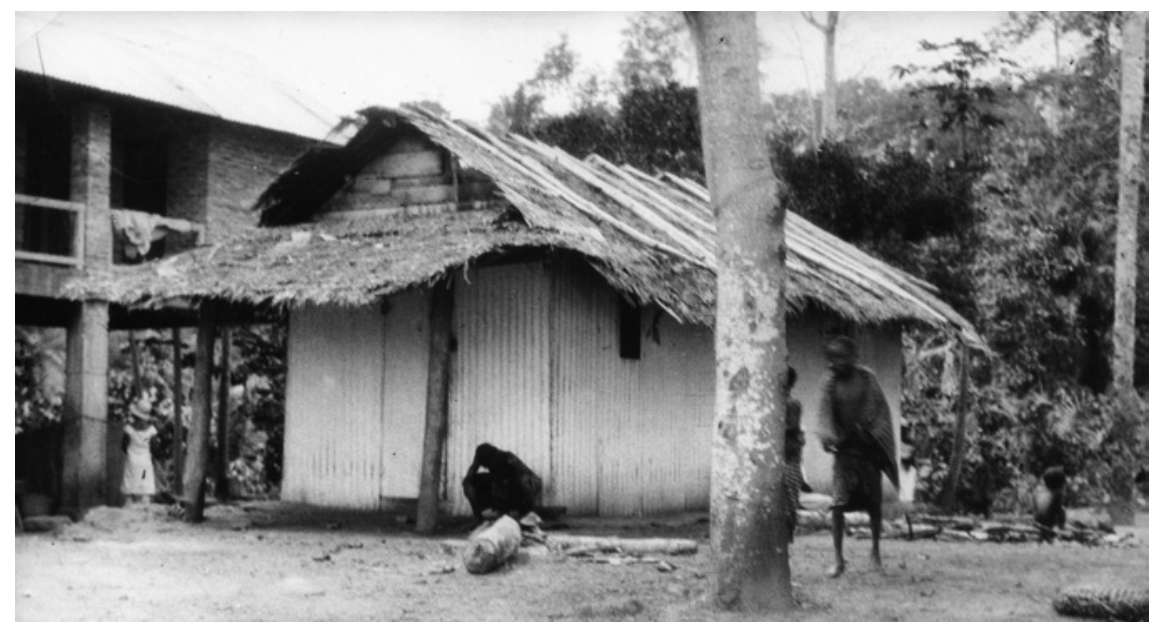

ILLUSTRATION 1 The former chicken coop at the mission station in Andendé, undated (C) ARCHIVES CENTRALES ALBERT SCHWEITZER GUNSBACH

there was a waiting area, a dormitory for patients, and dwellings for the first African auxiliaries, Joseph Azoawanié and N'zeng. ${ }^{2}$

Schweitzer claimed to have treated thirty to forty patients per day in this period. ${ }^{3}$ The vast majority required ambulant treatment; he recorded an average of only four inpatients per day between June 1913 and October $1917 .{ }^{4}$ When World War One started, the Schweitzers, as German citizens, were put under detention on the on the mission grounds. In 1917, they were forced to leave the French colony and were interned in France until the war was over, when they became French citizens. It took Schweitzer some time to recover from his internment and to collect the necessary funds for a recuperation of the hospital. Arriving back in Gabon in April 1924, Schweitzer had to undertake extensive renovations of the hospital buildings, which marked the beginning of the second phase (see Illustration 2). Due to tuberculosis, Helene was compelled to remain in Europe temporarily. He was accompanied by Noel Gillespie, a student at Oxford, whose mother, Emily Rieder, maintained close contact with Schweitzer. When in late 1924, a famine and a dysentery epidemic, which

2 Schweitzer, 'Notes et Nouvelles de la part du prof. Albert Schweitzer. Deuxième rapport', $3^{2-35}$. African medical personnel was usually refered to as '(Heil-) Gehilfe', more rarely as 'Pfleger'. I will use auxiliary, assistant, and aide interchangeably. When I do not give their full names, it is because they are not mentioned in the sources.

3 Ibid., 14 .

4 In total, 4,153 inpatients were accommodated at the hospital in this period. See the 'cahiers des patients', $\mathrm{L}-\mathrm{P}-\mathrm{C} 1, \mathrm{~L}-\mathrm{P}-\mathrm{C} 2$, AMs. 


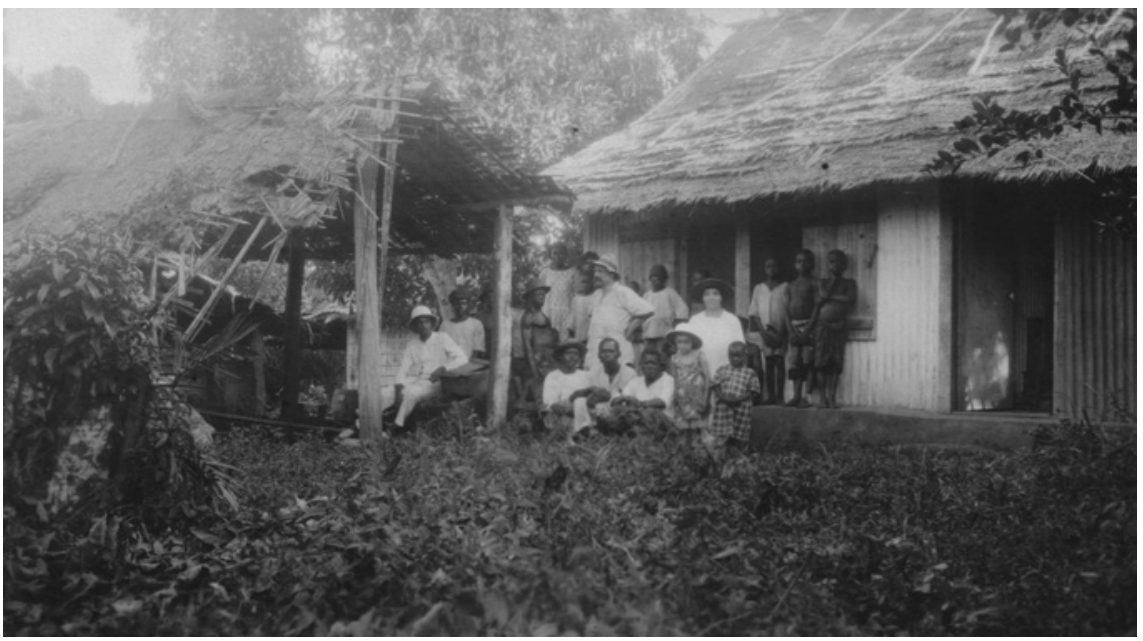

ILLUSTRATION 2 The ruinous hospital in April 1924

(C) ARCHIVES CENTRALES ALBERT SCHWEITZER GUNSBACH

would both last in varying intensity for two years, hit the region, Schweitzer concluded that the capacity of his hospital was insufficient. ${ }^{5}$ Increasingly tense relations with the mission facilitated his decision. ${ }^{6}$ Gillespie wrote to his mother in 1924 that Schweitzer was looking for a new site, because he was 'in very bad odour with the French official circles of the Paris Mission'. ${ }^{7}$ By February 1926, with patient numbers steadily increasing, it seems that he was pushed to leave the mission grounds. ${ }^{8}$

Schweitzer thus acquired land three kilometers upriver to construct a new hospital, which he designed himself. He mentioned only in passing that King Nkombe, he referred to him as the 'Sun King', had lived there. ${ }^{9}$ After 1924, Schweitzer was constantly supported by at least one doctor from Europe. Consequently, he was able to dedicate himself more frequently to working on the construction site. He was particularly proud of his architectural style: onestory wooden buildings on timber piles with ribbed roofs and excellent air

5 Schweitzer, 'Mitteilungen aus Lambarene. Zweites Heft, 1924-1925', 156-61. For more on the famine see: Mabika, 'La famine dans les Nouvelles de l'hôpital Albert Schweitzer'.

6 Scholl, Von der Ehrfurcht vor dem Leben zur transkulturellen Solidarität, 94-98. In 1923, Schweitzer had concretely considered to establish a hospital under the auspices of the Basel Mission in Cameroon in case the PEMS would obstruct his plans in Lambaréné.

7 Gillespie to Rieder, 26 April 1924, AWHs.

8 Schweitzer to Royden, 22 February 1926, AMs.

9 Schweitzer, 'Neues von Albert Schweitzer Pfingsten 1927', 5. 
circulation..$^{10}$ Another priority was the establishment of plantations, especially for plantains, which were to guarantee the institution some degree of selfsufficiency. ${ }^{11}$ Just like the rest of the hospital, these plantations would grow considerably in both extent and variety over the years.

\section{Patient Numbers: Reflecting Global and Local Events in Orderly Records}

At the beginning of 1927, the whole enterprise was moved to its new location. This marks the beginning of the third phase, which would last until 1981, when the new hospital, still in use today, was opened..$^{12}$ For the purposes of this study, it is helpful to subdivide this phase. Patient numbers serve as a useful guideline. They reflect how local realities, including the presence of a large timber industry, and global events, such as the Great Depression or World War Two, influenced hospital consultations.

Schweitzer had introduced a rigorous order in his files, which was maintained during his lifetime: the 'appels mensuels'. These were consistently recorded in a similar manner throughout the study period, thus equipping the historian with a continuous set of records. In 1935, Schweitzer described the recording procedure as follows: on the last day of each month, Dominique Bouka, an African assistant who was particularly trusted, summoned the patients by their place of origin, namely from which lumber station or region they came. They then had to enter the consultation room, where all the doctors, nurses, auxiliaries and interpreters would be seated at a table, before the patients' names, places of origin and diagnoses were recorded in the books (see Illustrations 3 and 4). Many relevant issues would also be discussed, including diagnosis and care, possible date of release, ability to work, and supply of food. The whole procedure lasted for only about four hours. ${ }^{13}$

Figure 1 shows the total number of inpatients treated each year. There is a high degree of uncertainty for many of these numbers, primarily because of the inconsistency and irregularity of the records. ${ }^{14}$ Figure 2 is based on the

\footnotetext{
10 Schweitzer, Mitteilungen aus Lambarene. Drittes Heft, 1925-1927, 19-27.

11 Ibid., 9-13.

12 Mabika, 'L'hôpital Albert Schweitzer de Lambaréné', 207.

13 Schweitzer, 'Briefe aus dem Lambarene Spital November 1935', 13.

14 The numbers haven been compiled with information from the following documents: 'Statistiques de l'Hôpital', L - A - S1-3, AMs; appels mensuels, L - P - C1-16, L - P - AM3-11, AMs; Association française des Amis d'Albert Schweitzer, 'Lactivité de l'Hôpital de Lambaréné 1965', AMs.
} 


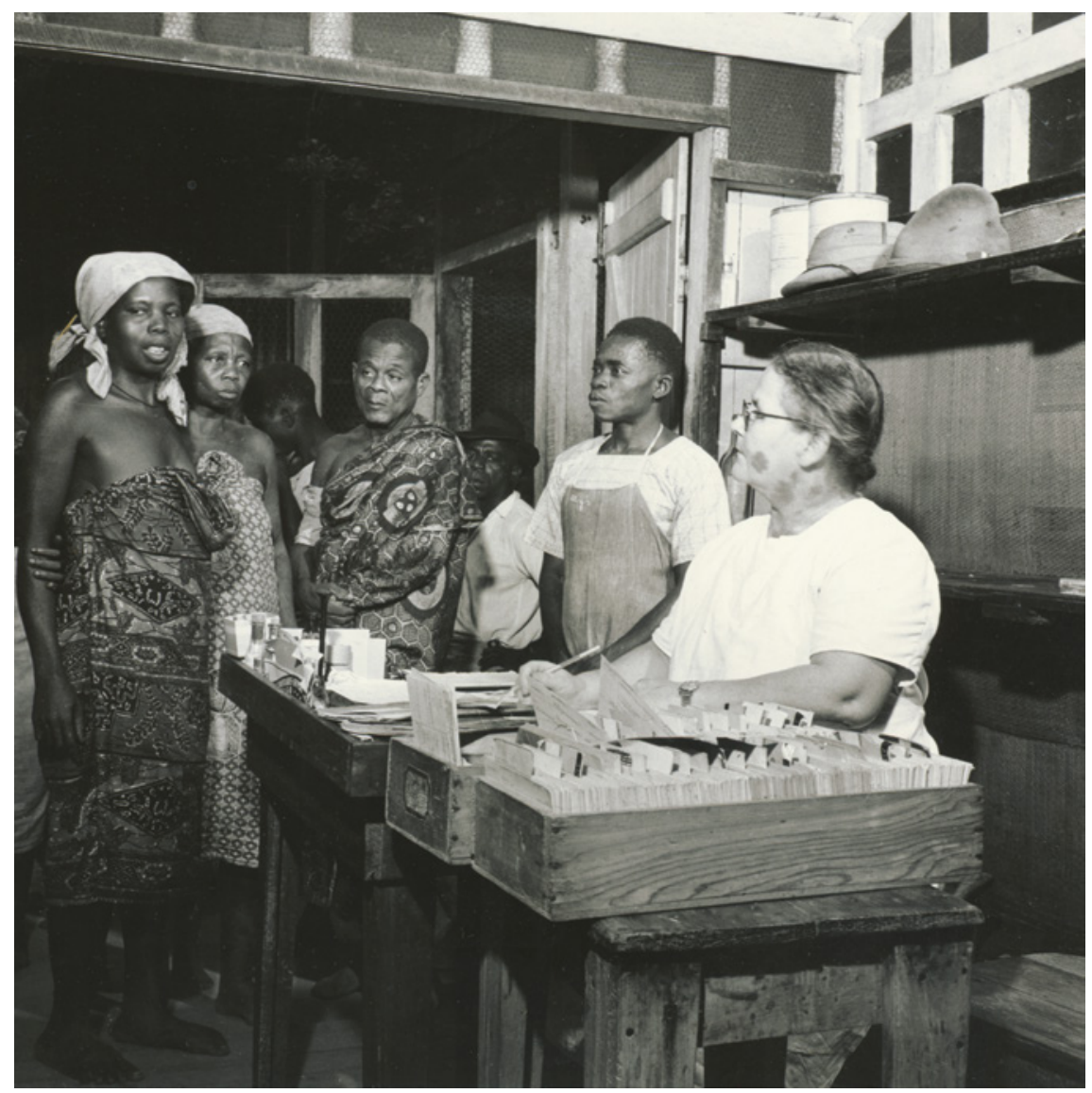

ILLUSTRATion 3 The nurse Gertrude Koch and the interpreter Auguste at the appels mensuels, ca. $195^{\circ}$

(C) ARCHIVES CENTRALES ALBERT SCHWEITZER GUNSBACH

appels mensuels and illustrates the approximate average number of inpatients present at any moment within the year. ${ }^{15}$ The graphs show three notable decreases in patient numbers. The first in 1930/31 has to do with the Great Depression, when numerous laborers left the region, while that from 1940 to 1943 is connected to World War Two, during which Schweitzer lost much of his funding and had to consequently turn away a considerable number of patients. The third drop, in the early 1950s, is due to a change in recordkeeping. From $195^{1}$ onwards, leprosy patients, of whom there had previously been as many as 160 on the list, were no longer recorded. The greatest influx of patients

15 The number for each year is the sum of the monthly figures divided by twelve. 


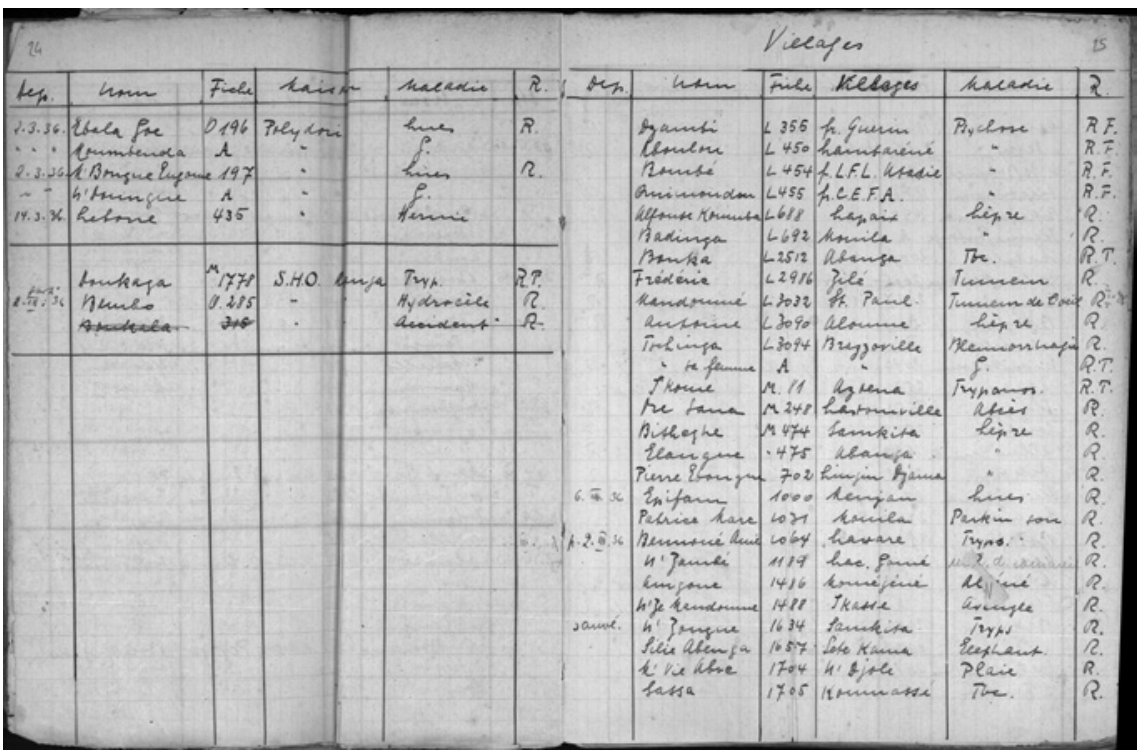

ILlustration 4 A page of the appels mensuels of 1 March 1936. Patients from maisons were recorded separately (left side)

(C) ARCHIVES CENTRALES ALBERT SCHWEITZER GUNSBACH

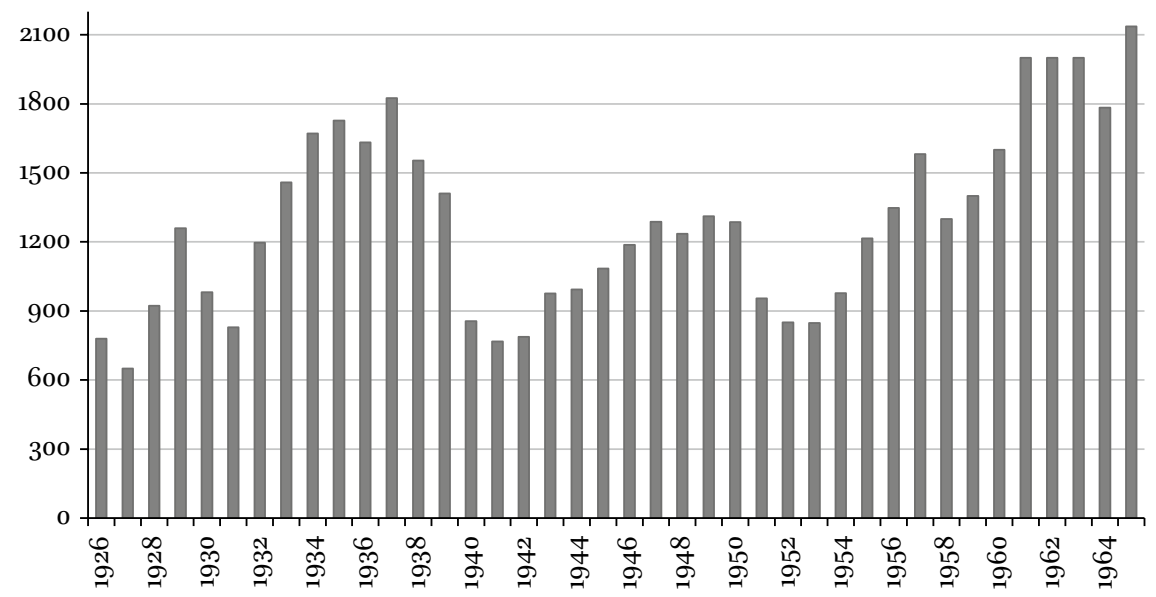

FIGURE 1 Total inpatients

only happened in the late 1950s and early 1960s, coinciding with Gabonese Independence that started to take shape in 1958. Mabika argues that in its wake government health services functioned less reliably. ${ }^{16}$ Only at this point

16 Mabika Ognandzi, Médicaliser l'Afrique, 233-36. 


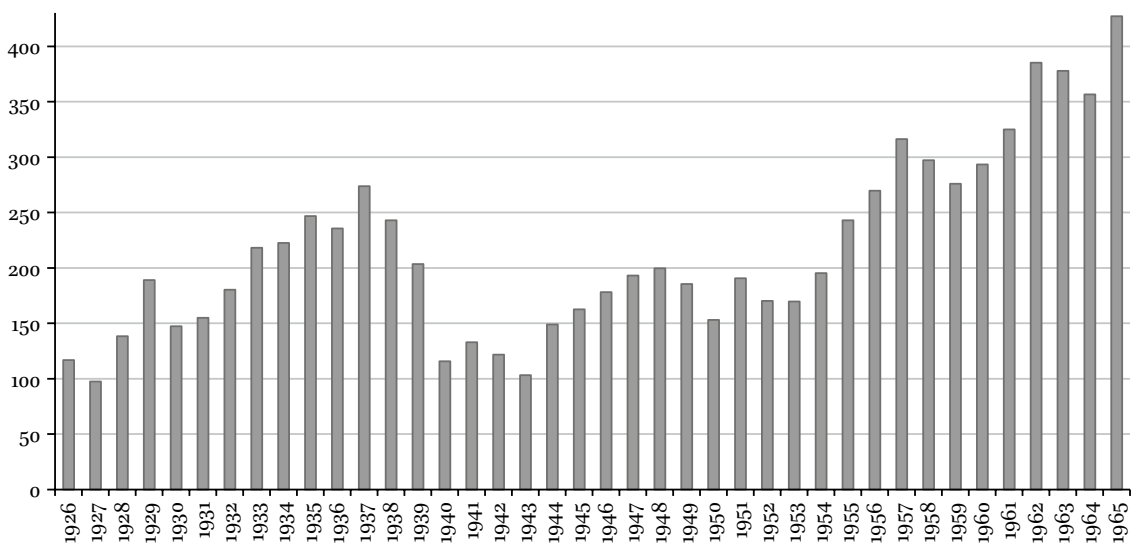

FIGURE 2 Average number of patients present

the Albert Schweitzer Hospital exceeded the initial importance that it had established for itself in the mid-1930s, at least if we judge its status solely by the numbers of patients treated.

Another major weakness of both of these graphs, and indeed of most sources, is that they do not include the outpatients. Dr. Rolf Müller claimed that in the late $1950 \mathrm{os}$ and early $1960 \mathrm{os}$, two thirds of all patients were outpatients. ${ }^{17}$ This suggests that they significantly increased in proportion: the statistics available for the 1930 s and early 1940 indicate an outpatient percentage of between $5^{0}$ and $60 .{ }^{18}$

Figure 3 shows the percentage of patients who came from 'maisons', sampled for every even year. Maisons were primarily lumber factories in the area, but also included smaller trading companies or missions. ${ }^{19}$ These patients may have tended to stay longer than others due to the severity of their afflictions, which might constitute one reason for their disproportionate representation in the statistics. However, Rita Headrick has also observed that in the 1920 s as many as half of all hospital patients in Gabon were loggers from the timber industry. This illustrates that health services were concentrated in areas of administrative or economic interest. ${ }^{20}$ Schweitzer's hospital was no exception.

\footnotetext{
17 Müller, '5o Jahre Albert-Schweitzer-Spital', 4.

18 See the 'Statistiques de l'Hôpital', L - A - S1-3, AMs. The highest percentage of outpatients during this period was recorded in 1931 (1441 or 63 percent of the total). The lowest was in 1935 when 1510 outpatients made up 46 percent of all patients recorded.

19 Presumably for reasons to do with payment, the appels list patients from maisons separately.

20 Headrick, Colonialism, Health and Illness in French Equatorial Africa, 213.
} 
Figure 3 reveals the profound influence of the timber industry in the surrounding region. Before the severe economic crisis of the early 1930s, between twothirds and three-quarters of all inpatients at the hospital came from maisons. Thereafter, other patient groups predominated, with still an average of approximately a third of all inpatients listed as coming from maisons. An unsurprising drop in patient numbers occurred during World War Two, followed by a less explicable decrease in 1950. Finally, the graph shows that the rise in patients after independence was mainly due to the arrival of new categories of patients, particularly women as evidenced in Figure $4 .{ }^{21} \mathrm{~A}$ more detailed discussion of female patients in their own right follows in Chapter 3 .

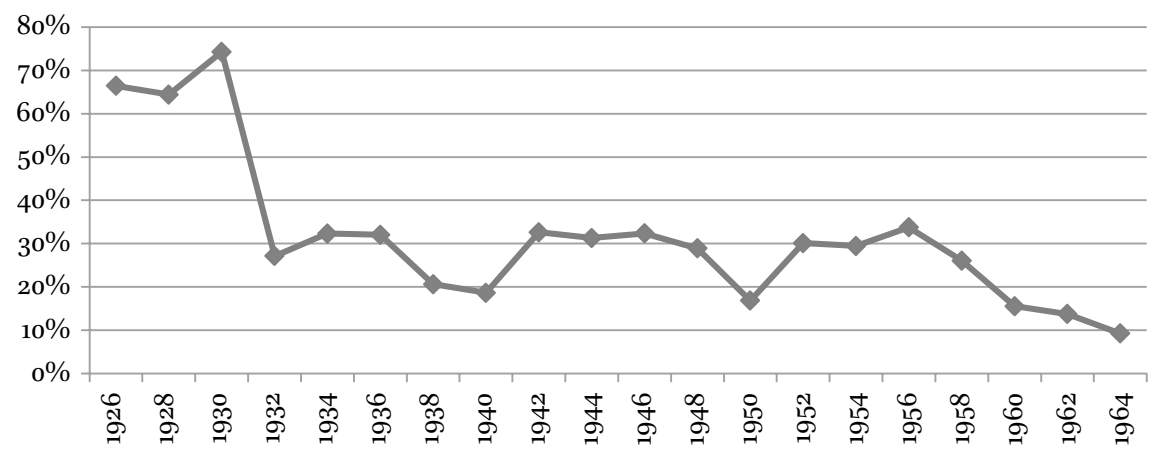

FIGURE 3 Percentage of inpatients from 'maisons'

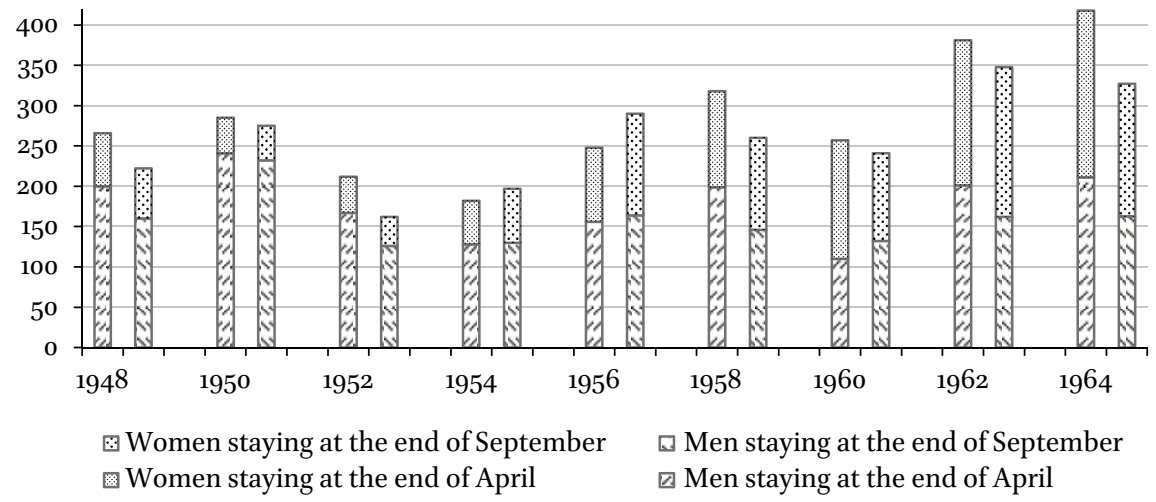

FIGURE 4 Gender ratio of inpatients

21 The data for Figure 4 is taken from the appels mensuels and is based on surnames; prior to 1948, these were not consistently and clearly recorded. I have sampled every even year. 


\section{Patients and Their Stay: Strict Conditions, Varied Degrees of Enforcement}

Patients did not usually arrive at the hospital on their own, but were accompanied by family members, the 'therapy managing group.' ${ }^{22}$ In fact, hospital rules dictated that each patient had to bring at least one 'gardien', as the staff referred to a patient's companion. These were to provide basic care, including cooking for and washing the patient. In practice, Schweitzer admitted that many patients came without their gardiens. ${ }^{23}$ Indeed, the appels mensuels show that the number of gardiens present was normally between one-quarter and one-third of that of patients, while this ratio decreased slightly further towards the end of the study period. However, the appearance of gardiens in the sources is so consistent that it is likely that the presence of many were not recorded officially in the appels mensuels.

In the 1930s, patients regularly arrived by boat, some from as far afield as 500 kilometers away. ${ }^{24} \mathrm{On}$ arrival, they would wait with their relatives in the yard in front of the 'Grande Pharmacie', the hospital's central building (see Illustrations 5 and 6). This was a pile construction, which provided shade and shelter. After being summoned by a doctor, the patients proceeded to the consultation room. ${ }^{25}$ At the first consultation, each patient received a ticket, a system that Schweitzer had introduced during his first stay. Patients rarely lost this small piece of cardboard and they often brought it around their neck along with a mark that the colonial government distributed to confirm the payment of the head tax. ${ }^{26}$ Specified on this ticket were the patient's name, date of arrival, age and hometown as well as a diagnosis. The patient was assigned a number in order to be easily found in the records. ${ }^{27}$ To facilitate patients' journey home, staff attempted to negotiate lifts with every passing boat. Moreover, departing patients were provided with food and those who had worked received a gift. ${ }^{28}$

Based on this data, April was most frequently the month with the highest number of patients present, September most often the one with the lowest.

Janzen, The Quest for Therapy, 4. Janzen defines the therapy managing group as 'kinsmen or their advocates' who oversee and organize the patient's illness and therapy.

Schweitzer, 'Briefe aus dem Lambarene Spital November 1935', 8.

Schweitzer, 'Briefe aus dem Lambarene Spital Juli 1933', 9.

Schweitzer, 'Briefe aus dem Lambarene Spital November 1935', 4.

Schweitzer, 'Notes et Nouvelles de la part du prof. Albert Schweitzer Lambaréné', 8.

Schweitzer, 'Briefe aus dem Lambarene Spital November 1935', 9.

Ibid., 11. 


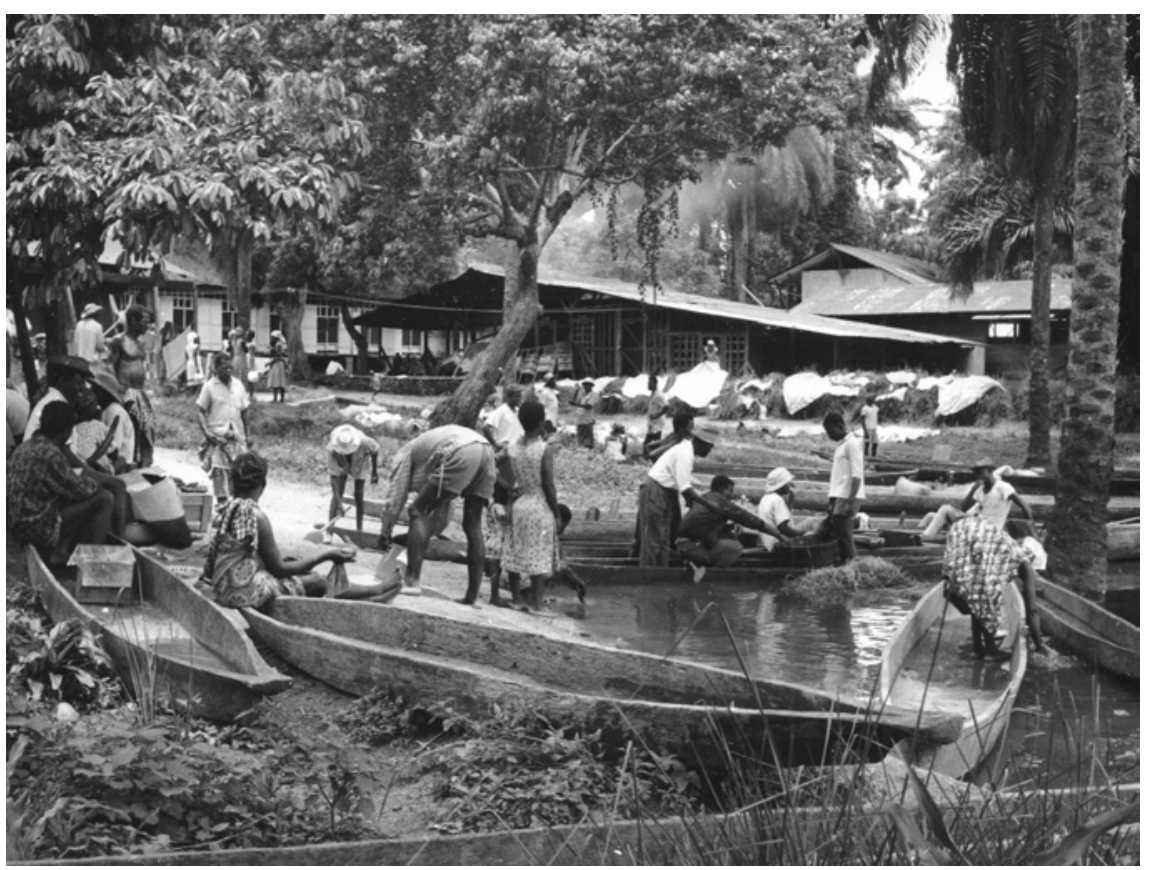

ILLUSTRATION 5 Patients and gardiens at the landing area during rainy season, late 1940s (C) ARChives CENTRALES Albert SCHWEitzer GUNSBACH

In 1925, this reportedly consisted of knifes, pots, cloth or similar items. ${ }^{29}$ In later years, salt, linen bags and money were mentioned..$^{30}$

Additional details about patient routines at the hospital from the early $1960 \mathrm{~s}$ can be reconstructed through interviews. ${ }^{31}$ On arrival, possible since 1939 by a road linking Libreville and Lambaréné, patients waited in the aforementioned yard next to a sign indicating 'new patients'. A nurse or auxiliary would then refer them to a doctor, assisted by an interpreter, in one of the three consultation rooms in the Grande Pharmacie (see Illustration 7). ${ }^{32}$ These contained tables behind curtains. According to a long-standing schedule, operations were performed on Tuesdays, Thursdays and Saturdays. On these days, only one

\footnotetext{
29 Schweitzer, Mitteilungen aus Lambarene. Drittes Heft, 1925-1927, 7.

3o Zellweger, 'Grosskampftag im Spital', 97-98.

31 Interview Elisabeth Anderegg; Group Interview Speicherschwendi; Interview Munz and Munz; Interview Hedwig Schnee.

32 Interview Munz and Munz.
} 


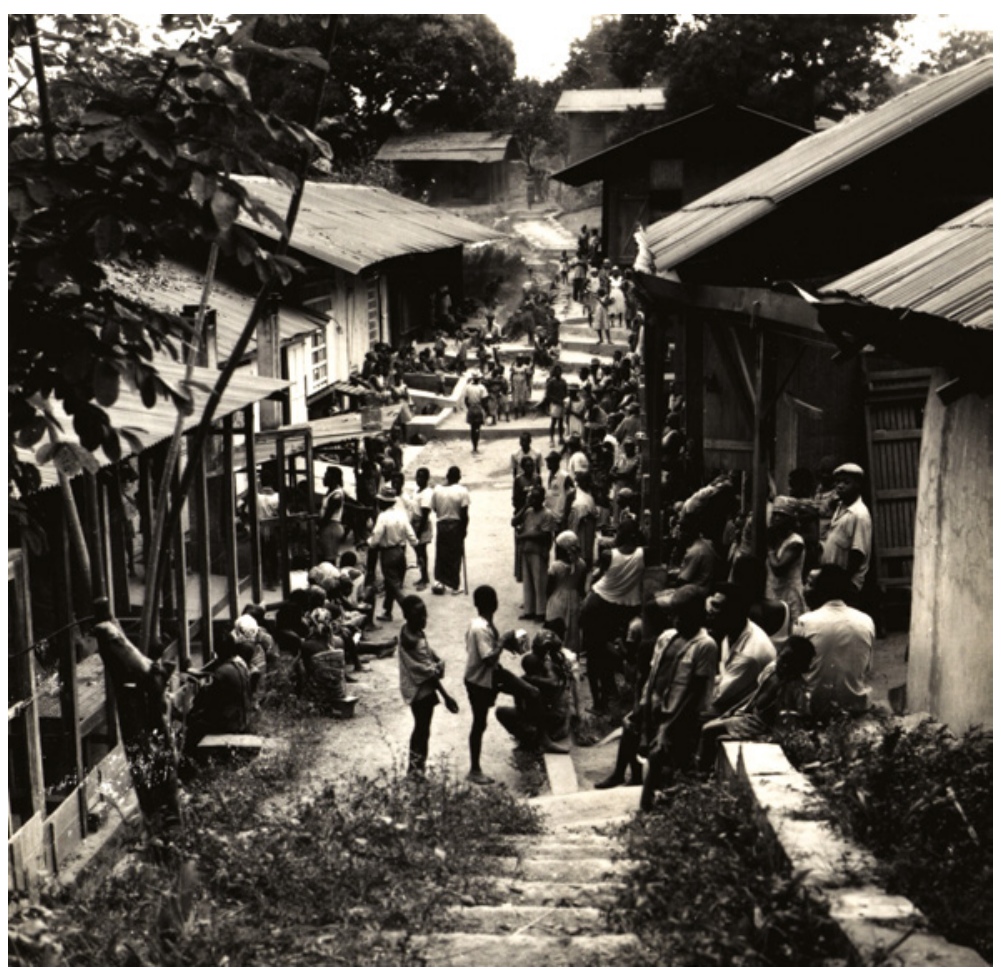

ILLUStration 6 The hospital's 'main road' with the Grande Pharmacie, the long building to the left, mid-1950s

(C) ARChives CENTRALES ALbERT SCHWEitzer GUNSBACH

table and one doctor were available for consultations. This schedule, however, was not overly strict due to the regular demand for emergency treatments.

If it were not a patient's first consultation, he or she would present the ticket to allow the doctors to check the registers, which dated back to 1913. There was always an interpreter present, even though many patients spoke at least some French. According to Dr. Walter Munz the patient-doctor encounter of the early 1960 occurred in a typically biomedical fashion: the doctor would listen to the patient's history and eventually establish a diagnosis. ${ }^{33}$ Recurring reports suggest that patients often expected the physician to know what was wrong with them before the consultation commenced. ${ }^{34}$ According to the

33 Ibid.

34 Group Interview Speicherschwendi; Mai, Albert Schweitzer und seine Kranken, 11-13. 


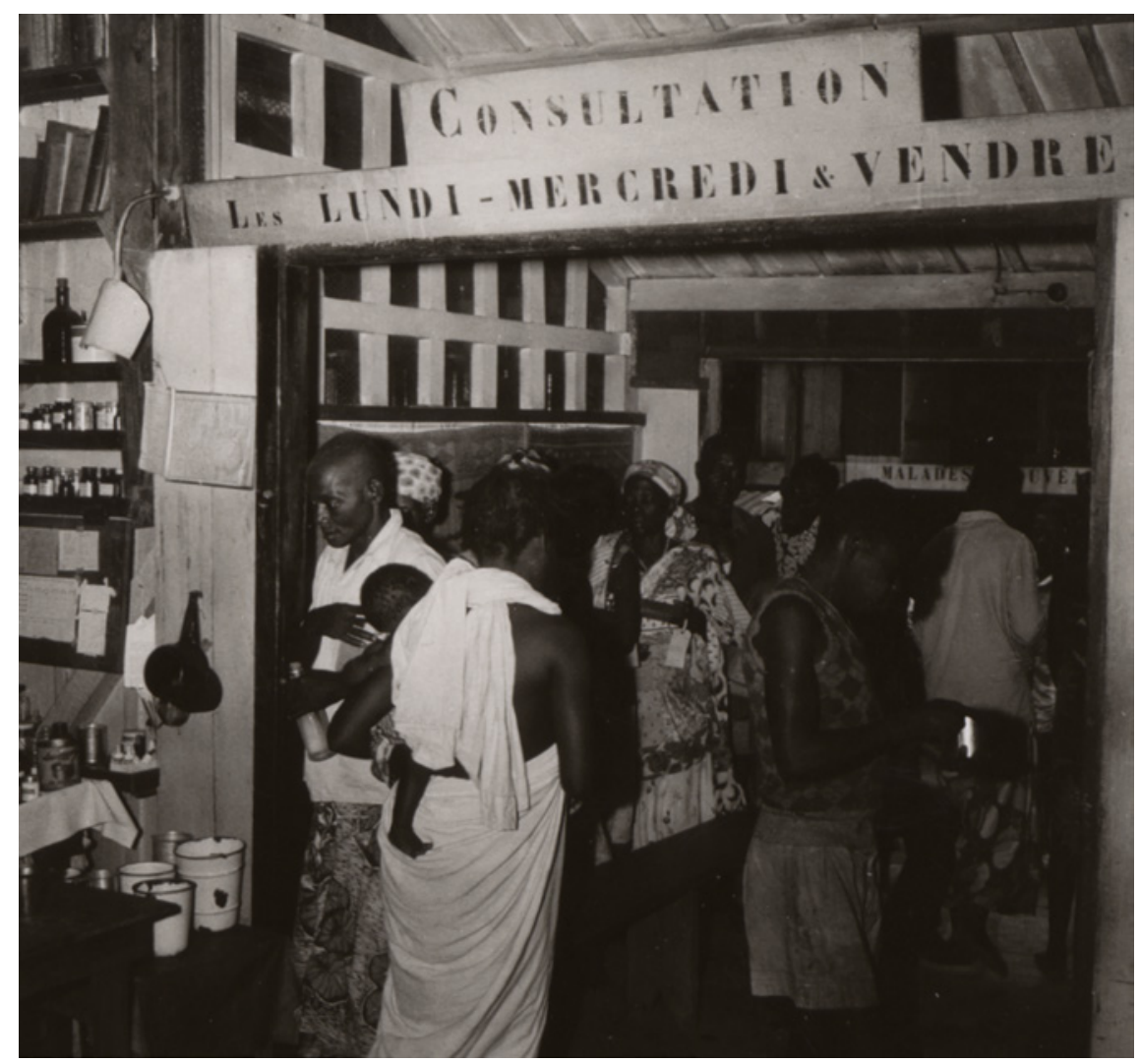

ILLUSTRATION 7 Patients at the consultation space, mid-1950s

(C) ARChives CENTRALES ALBERT SCHWEitzer GUNSBACH

nurse Elisabeth Anderegg, in the frequent case of overtly visible conditions such as elephantiasis, ulcers and hernias, this was often easy to achieve. ${ }^{35}$ From the doctors' perspective, patients tended to seek help when their afflictions were already too advanced, a frequently formulated complaint. ${ }^{36}$ Eventually, the doctor would write the proposed treatment on a piece of paper. This was then handed to the patient, who was instructed to do as advised. Treatments could include, for example, taking an antibiotic for a specified number of days, visiting the injection room, or undergoing blood tests in the laboratory. ${ }^{37}$

35 Interview Elisabeth Anderegg,

36 Two examples from different periods: Cousins, Dr. Schweitzer of Lambaréné, 138; Schweitzer, Mitteilungen aus Lambarene. Drittes Heft, 1925-1927, 46.

37 Interview Munz and Munz. 
The nurses from the ward to which the patient was assigned checked the ticket. Many wards maintained their own registers. After the prescribed therapy was completed, patients returned to the doctor for further consultations. ${ }^{38}$ When patients had to take a certain medication they were ordered to go to the pharmacy with their ticket whenever the on-duty nurse or African assistant rang a bell. There they received a pill, which they had to swallow on the spot to ensure compliance with the treatment regime and because the hospital authorities wanted to make sure that the patient did not sell it. ${ }^{39}$ The nurse Marianne Stocker recalled this to be a very impersonal process. 'It's like a factory', she noted in her diary. ${ }^{40}$

The hospital provided food to people coming from further than forty kilometers away (see Illustrations 8 and 9). For Schweitzer, the ideal diet for his patients consisted of manioc and plantains. In reality, often half of the food given to patients consisted of rice. ${ }^{41}$ In the 1930 s, approximately sixty kilograms of rice were distributed each day. In addition, patients received a daily portion of salt and palm oil, as well as imported dried fish on two or three occasions per week. ${ }^{42}$ In the early 1960 s, patients received alternating meals of rice and plantains and manioc or dried fish 'every now and then'. ${ }^{43}$ Siegfried Neukirch, who worked as a mechanic at the hospital from 1959 to 1965 , claimed that four to six tons of plantains were required per week, which he fetched from surrounding villages. ${ }^{44}$ In addition, local women continued to bring agricultural produce and other goods to the hospital each Thursday. ${ }^{45}$

Patients were free to choose their own beds. With equipment in the quarters being sparse, they had to bring their own blankets and sheets. ${ }^{46}$ Housing was segregated; the Galoa and the Fang had their own buildings. ${ }^{47}$ To the proposal by Anderegg that these should be combined, Schweitzer replied: 'That doesn't work. They would kill each other.48 It is not clear if this segregation was

38 Ibid.; Group Interview Speicherschwendi.

39 Interview Elisabeth Anderegg; Interview Hedwig Schnee.

40 Stocker, 'Diary 1961-63', 20.

41 Zumthurm, 'Food at the Albert Schweitzer Hospital'.

42 Schweitzer, 'Briefe aus dem Lambarene Spital November 1935', 7-9.

43 Stocker, 'Diary 1961-63', 36.

44 Neukirch, 'Bananeneinkauf und Transporte', 41.

45 Stocker, 'Diary 1961-63', 5; Nüesch-Wohlfender, 'Hausfrauliches', 156.

46 Cousins, Dr. Schweitzer of Lambaréné, 92; Interview Hedwig Schnee.

47 Østergaard Christensen, At Work with Albert Schweitzer, 45; Siefert, Meine Arbeitsjahre in Lambarene 1933-1935, 178.

48 Interview Elisabeth Anderegg. This is one of the few points on which Audoynaud agrees with Schweitzer. Like Schweitzer, he argues that the different ethnic groups were very suspicious of each other. Ethnic segregation was thus not an innovation, he contends, but 


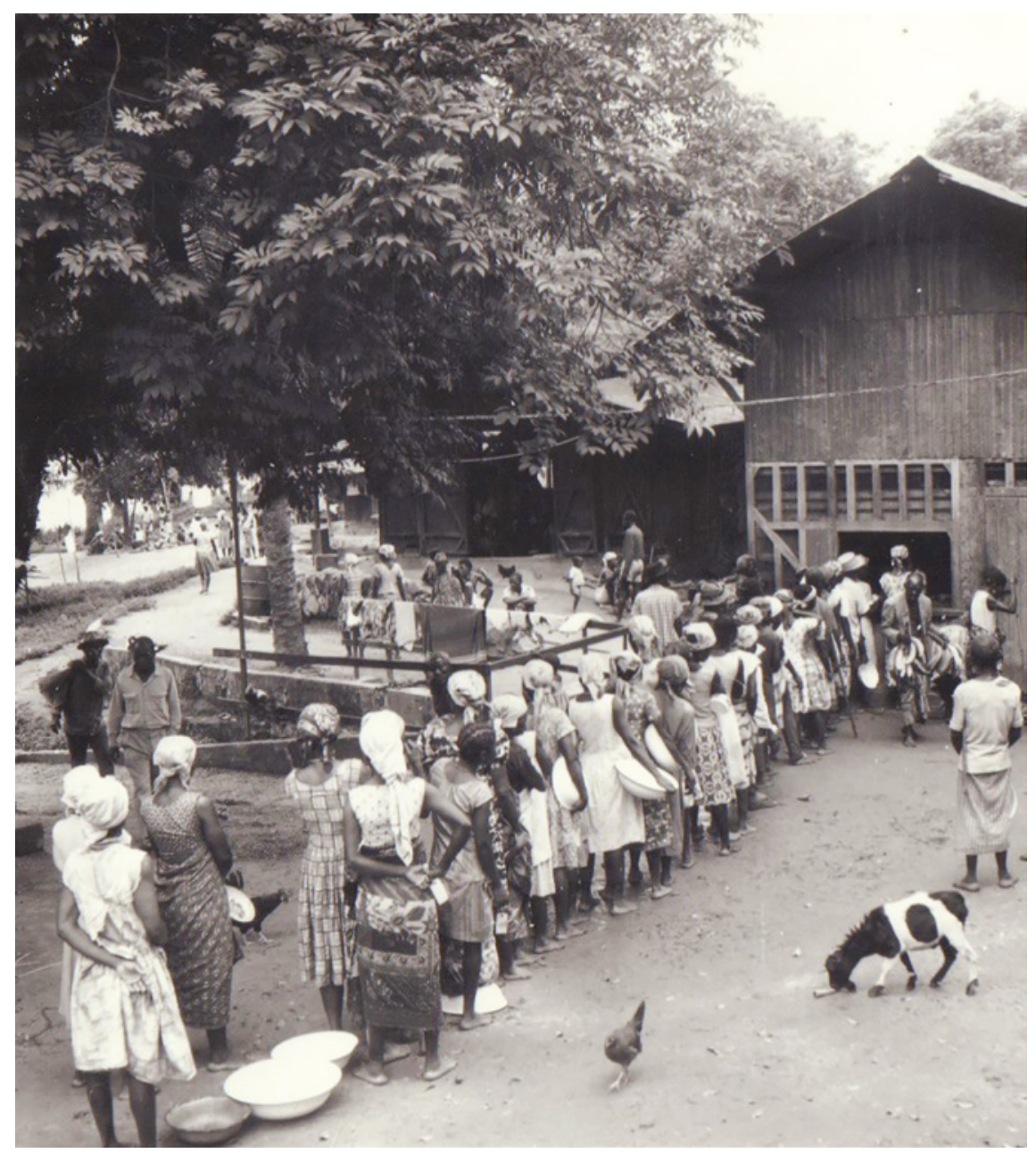

ILLUSTRATION 8 Patients or gardiens collecting their ration of food, mid-1950s (C) ARCHIVES CENTRALES ALBERT SCHWEITZER GUNSBACH

intentionally ordered or if it was the outcome of patients' free choice of beds. The fact that Schweitzer had not mentioned maintaining different buildings for different groups in his otherwise very detailed description of the new hospital in 1927 hints towards the latter. ${ }^{49}$ In any case, five years later, segregation

the inevitable result of the practical realities. See: Audoynaud, Le docteur Schweitzer et son hôpital à Lambaréné, 206.

49 Schweitzer, Mitteilungen aus Lambarene. Drittes Heft, 1925-1927, 51-53. 


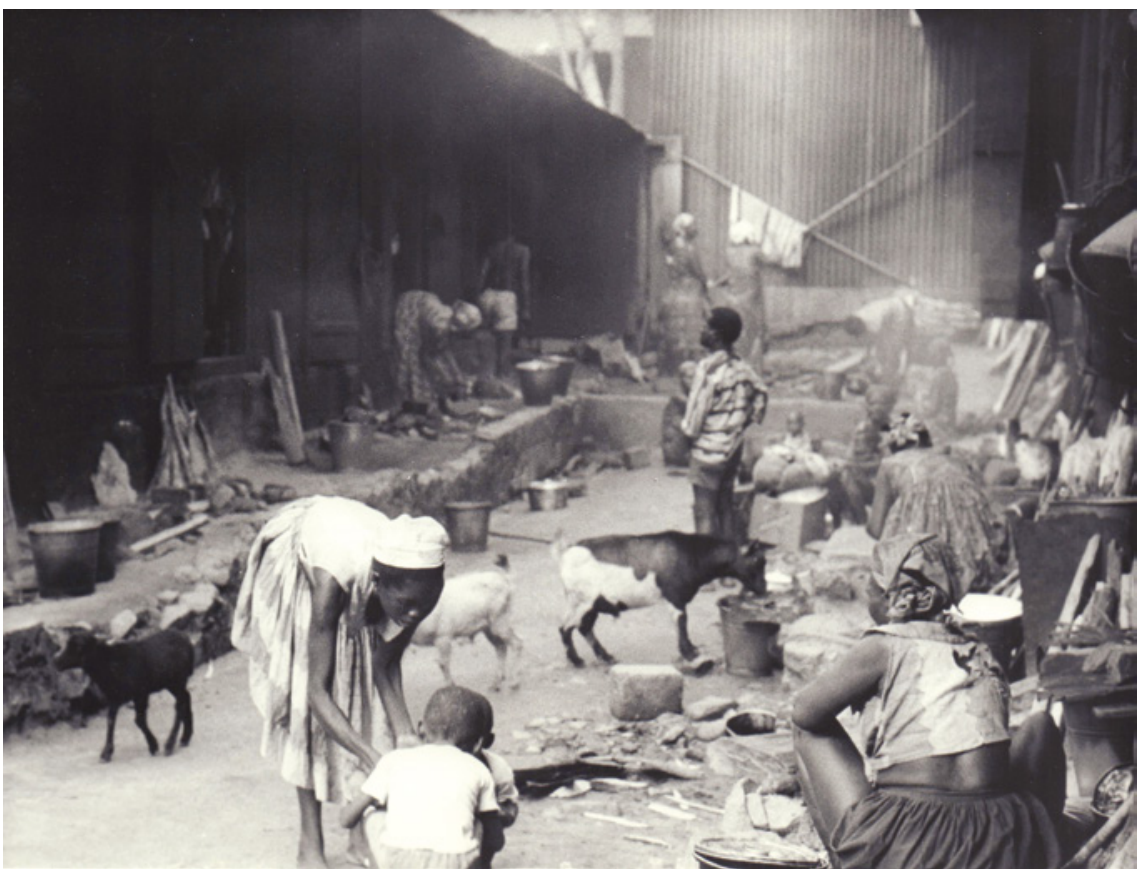

ILLUSTRATION 9 Patients or gardiens cooking their meals behind the sleeping quarters, mid-1950s

(C) ARCHIVES CENTRALES ALBERT SCHWEITZER GUNSBACH

had already become evident. ${ }^{50}$ The hospital did adapt to patients' demands in relation to accommodation, as a letter dating from 1929 suggests. Mathilde Kottmann, who would later become one of the key individuals in the running of the hospital, explained to Emily Rieder:

Two of the six hospital buildings house patients only, natives. Some of these buildings are even equipped a little more comfortably for the notables of the Galoas, who often refused to reside in the hospital because they could not be accommodated according to their status due to lack of space. ${ }^{51}$

5o I found this particular reference in a government report on Schweitzer's hospital: 'Rapport Annuel du Service de Santé de la Colonie du Gabon 1932', ZK 005-127, SHD. Schweitzer himself first mentioned this arrangement in the 1940s. See: Schweitzer, Das Spital im Urwald: Aufnahmen von Anna Wildikann, 15.

$51 \quad$ Kottmann to Rieder, 13 March 1929, AWHs. 
Treatment had to be paid for according to each patient's means. In this manner, Schweitzer hoped to ensure their gratitude. In 1931, he stated that he was satisfied when one-quarter or one-fifth of the expenses was covered. While he asked for twenty régimes of plantains and the presence of two workers during a patient's stay to cover the costs of an operation, he often had to be satisfied with only five régimes and a single worker. A patient who could not pay was treated free of charge. ${ }^{52}$ The Gabonese I interviewed reformulated this. They insisted that treatment at the hospital was 'gratis'. In their view, a patient did not have to pay, but gave a 'gift' or 'donation' in the form of fruit or chicken, for which Schweitzer showed his gratitude, saying 'thank you'.53 Emane reports a similar attitude among his informants. ${ }^{54}$

Everyone staying at the hospital, who was sufficiently fit, was expected to work. This included gardiens, but also recovering patients or those with minor illnesses. Jobs were gendered and work was constantly supervised by European doctors or nurses. Each Saturday at 2 p.m., every woman who was able to work was ordered to clean the hospital grounds. This procedure often continued until dusk. Waste was dumped into the river. ${ }^{55}$ Daily tasks were assigned before breakfast. At least six people were sent to gather wood from the forest, which was being rapidly denuded and had already been pushed back to a half hour's walk away by the mid-193os. One man was responsible for cutting this wood for the entire day. Others were assigned to the task of constructing new buildings. A dozen women were instructed to do the hospital's laundry. They had to wash bandages and hospital clothing as well as the clothes and bedding of European staff. Four women prepared palm oil from nuts gathered by two men, separating the oily mass from the kernels, which were later exchanged for rice. ${ }^{56}$ The compulsory gathering of palm nuts evoked painful memories in the area. During some of the interwar period, local residents who were unable to pay taxes to the French authorities were forced to collect palm nuts under a forced labor regime. ${ }^{57}$ Forced labor was also not uncommon at the hospital itself. For

52 Albert Schweitzer, 'Le secours médical aux colonies' in Revue des Deux Mondes September 1931. Cited in: Sorg, Schweitzer, le médecin, 39-40.

53 Group Interview Port-Gentil; Interview Daudette Azizet Mburu; Interview Jacques Boucah; Interview Anne-Marie Padje-Poabalou. More details and personal information on these interviewees follow in the subsequent chapters, when their individual stories contribute to the analysis of specific issues.

54 Emane, Docteur Schweitzer: une icône africaine, 117-18.

55 Schweitzer, 'Briefe aus dem Lambarene Spital November 1935', 12.

56 Ibid., 3 .

57 Gray, Colonial Rule and Crisis in Equatorial Africa, 182. 
example, the nurse Marie Woytt-Secretan described the process of producing palm oil in great detail:

If the women had been left to themselves, they would have gone up and away in the first unguarded moment, taking the oil with them. To prevent this, Doctor Schweitzer had built a large wire cage into which they were let in the morning with everything they needed to prepare the oil: Palm nuts, wood, water, kettles, etc. Then the cage was locked, and the sister did not have to check the work again until noon and let the workers out. ${ }^{58}$

Such drastic forms of supervision are frequently described in the sources, affecting not only workers but also patients. For the latter, this usually occurred in conjunction with a specific medical treatment. In 1926, for example, patients with intestinal worms were given thymol, which interacts dangerously with any kind of oil. Patients were suspected of not adhering to this dietary restriction; they were summarily confined behind bars. This measure had little effect: friends secretly brought them oily palm nuts. ${ }^{59}$ In 1935 , Schweitzer reported that Dominique Bouka summoned patients to their injections with a cow bell. As their number was considerable and the waiting period often lengthy, to reduce patients' temptation to spend their time elsewhere, they were locked in a barred area in front of the consultation room, from where they were fetched one after another. ${ }^{60}$ In 1939, Schweitzer proudly reported a new treatment for worms derived from chenopodium oil. To mitigate the risk that it could 'cause fatal bowel inflammation if the necessary precautions are not strictly adhered to', he ordered that the 'patients, large and small, are kept locked in a spacious wire mesh cage in front of the consultation room, so that they are under constant supervision'.61 Thereafter, reports of detention decrease. ${ }^{62}$ This might be due to the spread of more progressive attitudes, but may also be the result of the introduction of antibiotics. Further details on pharmaceutical treatment and confinement can be found in Chapter 4.

Such severe measures encouraged resistance. Instances of undesirable patient behavior frequently surface in the sources. Besides the theft of equipment,

$5^{8}$ Woytt-Secretan, Albert Schweitzer baut Lambarene, 71. She served as a nurse from 1929 to 1931.

59 Schweitzer, 'Neues von Albert Schweitzer Februar 1925', 5.

6o Albert Schweitzer, Schweitzer, 'Briefe aus dem Lambarene Spital November 1935', 4f.

61 Albert Schweitzer, Schweitzer, 'Briefe aus dem Lambarene Spital Februar 1939', 3f.

62 With the exception of 1948, when patients with amoebic dysentery were isolated in a house with a barred yard: Schweitzer, Das Spital im Urwald: Aufnahmen von Anna Wildikann, 13 . 
such as nets or bedding, a main concern throughout the study period was that patients did not rest enough. ${ }^{63}$ For example, some would go bathing in the river on the same day on which they were due to undergo an operation. ${ }^{64}$ Others left the hospital in the middle of a treatment that they viewed as hopeless, choosing instead to return to their villages. ${ }^{65}$ When Stocker went on a Sunday stroll in 1961, she met tuberculosis patients who had been prescribed strict bed rest. Their excuse was straightforward: it was a Sunday. ${ }^{6}$

\section{Patient Motivation: Conceptions of Health and Other Treatments}

Patients too were rather pragmatic in their approach towards their health and their selection of therapy. When asked about why patients would choose to go to the Albert Schweitzer Hospital, the answer given by my Gabonese interviewees was usually straightforward: it simply was the best hospital in Gabon, providing care that was patently superior to that offered in any government clinic. ${ }^{67}$ Included in this conception of superior care was the provision of food to patients and the opportunity for them to cook it themselves, as was the possibility of being accompanied by friends and family. ${ }^{68}$ Emane's informants confirm the centrality of food and cooking. ${ }^{69}$ Bringing companions relates to Emane's repeated claim that the hospital was valued locally because it did not simply treat the sick body; people there acknowledged that patients were human beings in their own right. Indeed, the 'humanity' exuded by the hospital and its staff is constantly underlined throughout his book. ${ }^{70}$ Similarly, most of my interviewees recalled the warm 'reception' that they received at the hospital. ${ }^{71}$ Ngouawiri Suzanne Rembendambja, one of the few former patients to whom I was able to talk, recounted that when she was sent to the hospital by her father in 1954, 'ah ... it was the loving reception, really that has cured me.'72

63 Haussknecht, Emma Haussknecht, 1895-1956, 111; Barthélemy, Wie ich Lambarene erlebte, 52.

64 In 1937, Schweitzer reported that this had been a regular occurrence throughout the hospital's history. See: Schweitzer, 'Briefe aus dem Lambarene Spital Mai 1937', 3.

65 Group Interview Speicherschwendi.

66 Stocker, 'Diary 1961-63', 16.

67 Interview Jacques Boucah; Interview Jacques-Adrien Rolagho.

68 Interview Albert Bouassa; Interview Jacques Boucah; Interview Jacques-Adrien Rolagho.

69 Emane, Docteur Schweitzer: une icône africaine, 44.

$70 \quad$ Ibid., 47, 177-80, 217.

71 Interview Daudette Azizet Mburu; Interview Marie-Joséphine Ndiaye-Boucah; Interview Léontine Nsowe; Interview Jacques-Adrien Rolagho.

72 Group Interview Port-Gentil. 
Readers of historical studies on colonial hospitals will have found many familiar issues in this examination of patient routines. Two themes are worthy of further emphasis. Firstly, it has long been observed that hospitals in Africa were often more open than their Western counterparts in permitting patients relatives or friends to stay with them for a prolonged period of time. ${ }^{73}$ This seems to be especially true for mission hospitals. ${ }^{74}$ The reasoning behind this approach was twofold. On the one hand, such openness and permeability were demanded from the therapy managing group and thus represented a precondition for luring patients to the hospital in the first place. On the other hand, companions provided basic nursing services that were often necessary given the lack of personnel in colonial hospitals. In Kalene Hospital in early-twentieth-century Zambia, this went so far that companions constructed the huts in which patients were accommodated. ${ }^{75}$ Schweitzer's insistence on manual labor and 'handicraft', as well as his demand that everyone at the hospital be put to work, are traces of the institution's missionary context. Chapter 5 explains the peculiar ideology that lay behind this approach.

Another issue that has been raised in this overview is the prevalence of medical pluralism in Gabon, an attitude that persists in both urban and rural settings today. ${ }^{76}$ Mabika argues that it only emerged after the colonial introduction of biomedicine and hospitals. ${ }^{77}$ Elsewhere on the continent, especially in regions where Islam was present, it remains unclear to what degree medical pluralism had already been a precolonial phenomenon. ${ }^{78}$ Many colonial doctors were aware of the fact that their patients regularly used a variety of different treatments. ${ }^{79}$ John Janzen has famously observed great pluralism in very few cases in postcolonial Congo. ${ }^{80}$ Ever since, the issue has attracted the attention of historians. Julie Livingston, for instance, provided an insightful

73 Feierman and Janzen, 'The Social Basis of Health and Healing in Africa, Introduction', 18.

74 These have also been the more frequent subject of historical research than government hospitals; they might have better preserved records. Examples of studies that mention patients' relatives staying at the hospital: Debusmann, 'Médicalisation et pluralisme au Cameroun allemand', 237-38; Pringle, 'Neurasthenia at Mengo Hospital, Uganda', 243; Ranger, 'Godly Medicine', 271; and one for a government context: Havik, 'Reconsidering Indigenous Health', 246.

75 Kalusa, 'Missionaries, African Patients, and Negotiating Missionary Medicine', 289.

76 Ebang, 'De la diversité des itinéraires thérapeutiques au Gabon'.

77 Mabika, 'Médicalisation de l'Afrique centrale', 436.

78 Dirar, 'Curing Bodies to Rescue Souls'; Iliffe, East African Doctors, 12; Olumwullah, DisEase in the Colonial State, 11.

79 Debusmann, 'Médicalisation et pluralisme au Cameroun allemand', 237; Bado, 'Histoire, maladies et médecines en Afrique Occidentale', 256.

$80 \quad$ Janzen, The Quest for Therapy, 150. 
expansion of the notion by examining 'productive misunderstandings', thereby increasing our understanding of how different medical systems operated together. ${ }^{81}$ The idea of medical pluralism, and indeed of medical systems themselves, has been widely criticized and refined. ${ }^{82} \mathrm{~A}$ central critique is that definitions are often imprecise and/or too broad. ${ }^{83}$ Walter Bruchhausen points out that this represents a genuine conceptual contradiction. Pluralism, he argues, 'refers to diversity as a necessity and claims to describe some unifying aspect. Thus at one and the same time it emphasises and denies the worth of a single concept ${ }^{\prime}{ }^{8}$

Outside of the Western world, illness has usually not been considered accidental. ${ }^{85}$ As Vansina, posits for Central Africa, 'illness was the quintessential manifestation of abnormality and abnormality always resulted from the neglect of spirits or attacks by witches'. ${ }^{86}$ In the case of the Fang of Gabon for the period around 1960, James Fernandez insists that 'any illness could be attributed to the maleficence of unseen forces', but that it could also be seen to be caused by 'contagion, worms, or accident'. ${ }^{87}$ Specialists thus had to be consulted to clarify the exact cause. ${ }^{88}$

The most prominent of these specialists was the 'Nganga'. According to sociologist Bernadin Mve Minko, a Nganga possessed a versatile set of tools. 'He

$81 \quad$ Livingston, 'Productive Misunderstandings'.

82 Stacey Langwick instead calls for a deeper analysis that 'looks at the times and ways that healers, clinical practitioners, government bureaucrats, medical scientists, and patients implicate the modern in the traditional, the clinic in the home of the healer, science in the nonbiomedical, and vice versa'. In: Langwick, Bodies, Politics, and African Healing, 236. On the questioning of systems, see most famously: Last, "The Importance of Knowing about Not Knowing'.

83 Waltraud Ernst, for instance, provides two definitions of medical pluralism, with the second more or less foregoing Langwick's call (see above footnote): (1) 'a variety of medial approaches existing alongside each other, at times in competition and at times in collaboration with or complementary to each other'. (2): 'the plural or multi-dimensional qualities inherent in medical practices and experiences, as these draw on and are open to different approaches, are "bastardised" or hybridised, syncretic, and versatile'. Ernst, Plural Medicine, Tradition and Modernity, 8.

84 Bruchhausen, 'Medical Pluralism as a Historical Phenomenon', 100.

85 Last, 'Non-Western Concepts of Disease', 642.

86 Vansina, Paths in the Rainforests, 98.

87 Fernandez, Bwiti, 190-91.

88 Ibid., 194. Fernandez identifies the Ngungan and the Nsônkngang. In his glossary, he defines the former as a "doctor", person powerful in the knowledge of hidden things, also a courageous one in dealing with the demon'. The entry for the latter is: 'he who searches out hidden things, "doctor" of powerful revelation'. Fernandez further states that the Nsônkngang is more powerful, but, having been targeted by the colonial authorities as a 'diviner', is now rarely found. Ibid., 222. 
knew magical practices: knowledge of plants, access to spirits, to ancestors and to prophylactic formulas', Minko writes. These corresponded to his broad responsibilities. A Nganga 'relieved human and physical misery and addressed the problems between the individual and his environment'. His expertise centered on his knowledge of the 'Tout Autre' and his ability to interpret the 'diverse levels of reality'. ${ }^{89}$ In his study on the Nkomi, a group that, like the Galoa, speaks the Myene language but lives further west, François Gaulme notes that 'any operation related to the supernatural can be within the domain of the oganga and also require his intervention. ${ }^{90}$ These accounts illustrate the difficulty to provide an accurate definition of what constitutes a Nganga without using European categories that are based on a separation of different levels of reality. As indicated in the Introduction, Gabonese did not necessarily make such a separation. For them, the invisible, for instance in the form of spirits, was an inherent part of Nature's reality.

Gaulme, who conducted his ethnological research in the 1970s, observes that descriptions of Nganga from late-sixteenth-century documents did not differ much from those found in studies written during his own lifetime. He further underlines that the Nganga did not necessarily remain in one village or treat only patients from his or her own ethnic group. ${ }^{91}$ In their book from 1962, Sillans and Raponda-Walker emphasized that Ngangas could be found in any ethnic group. According to them, the term had two meanings. The first was simply 'the one who makes a profession of caring for people' and explicitly included European doctors. The second related to 'occult practices - such as divination, magic'. According to the authors, most Ngangas combine these two roles in one person. As such, they are 'the intermediary between the visible world and the invisible world. ${ }^{92}$

In some of these accounts, another actor, more loosely defined, is present as a counterpart to the Nganga: the 'sorcerer', ${ }^{93}$ ' $w$ witch', ${ }^{94}$ or 'spellcaster'. ${ }^{95}$ As

89 Minko Mve, Gabon entre tradition et post-modernité, ${ }^{136-37}$. Minko Mve's spelling is 'Nguegan'. Italics in the original.

9o Gaulme, Le pays de Cama, 209.

91 Ibid.

92 Sillans and Raponda-Walker provided the following spellings: Ngang or Uganga in Fang; Oganga in Myene; and Nganga in Eshira, Mitsogo and many other languages. They insisted that Ngangas did not practice witchcraft, but instead used their powers to find out if a particular affliction was provoked by witchcraft. See: Raponda-Walker and Sillans, Rites et croyances des peuples du Gabon, 32-33. Italics in the original.

93 Minko Mve, Gabon entre tradition et post-modernité, 139. His French term is 'sorcier'.

94 Fernandez, Bwiti, 222.

95 Raponda-Walker and Sillans, Rites et croyances des peuples du Gabon, 33. They use the term 'jeteurs de sorts'. 
discussed in the Introduction, more recent research on the region generally insists on the impossibility of separating the spheres of religion, politics, and medicine. As a result, the two figures are usually grouped together. Hines Mabika suggests that there was a variety of Ngangas, with some specializing in different areas. ${ }^{96}$ Their overall aim, however, was to 'prevent evil or disease, in the form of disrupted life-force balances, or in the form of a separation between the normal and the pathological. ${ }^{97}$ Florence Bernault highlights in the case of the French Congo that the dichotomy between 'banganga (fetisher)' and 'bandoki (sorcerer)' has seldom stood up to scrutiny. Instead, it was a colonial construction with its roots in the politics of the day. ${ }^{98}$

After this discussion of treatments options one is tempted to conclude that good health according to local conceptions depended on an 'equilibrium,' ${ }^{99} \mathrm{a}$ 'wholeness', ${ }^{100}$ a 'general integrity of feeling and thought in human affairs'.101 Janzen suggests that the unwillingness of biomedical practitioners to explore the social and personal contexts of disease accordingly reinforced 'the popular image of Western medicine's limited competence'.102 However, various scholars remind us of the 'harming' side of African healing. ${ }^{103}$ It was not necessarily 'benign and benevolent' for everyone involved. ${ }^{104}$ This view is supported by the indistinctiveness of what were considered the destructive 'sorcerer' and the constructive 'fetisher' from above. I will discuss these themes in more detail in Chapter 5 .

To return to the issue of pluralism it is instructive to ask when patients would seek to consult the Nganga. Mabika, writing of the pre-colonial era, highlights that patients would try to treat themselves or consult family members before going to the Nganga. ${ }^{105}$ During colonial times, Minko argues the Nganga remained the final option, being consulted only after the biomedical doctor. ${ }^{106}$ In our sources, however, there are abundant reports of patients having undergone earlier treatments. In any case, it might be misleading to distinguish between an African Nganga and a European physician. For Emane, it is

\footnotetext{
96 Mabika Ognandzi, Médicaliser l'Afrique, 81-82.

97 Mabika, 'Médicalisation de l'Afrique centrale', 94.

98 Bernault, 'De la modernité comme impuissance'.

99 Mabika Ognandzi, Médicaliser l'Afrique, 85.

100 Vansina, Paths in the Rainforests, 328.

101 Fernandez, Bwiti, 192.

102 Janzen, The Quest for Therapy, 215.

103 Hunt, 'Health and Healing'.

104 Vaughan, 'Healing and Curing', 293. See also: Bernault and Tonda, 'Dynamiques de l'invisible en Afrique'.

105 Mabika, 'Médicalisation de l'Afrique centrale', 408.

106 Minko Mve, Gabon entre tradition et post-modernité, 138.
} 
obvious that Schweitzer was considered to be an Nganga; there were many similarities. Just like a Nganga, Schweitzer trained successors, played music and was attached to a specific location. ${ }^{107}$ Schweitzer asserted that locals called him Nganga during his first stay. ${ }^{108}$ Munz also claims to have been addressed as Nganga ${ }^{109}$ which suggests that the term was applied broadly. Such congruities or 'productive misunderstandings' are important to understand why Gabonese would choose the Albert Schweitzer Hospital for treatment.

Another point concerning the acceptance of new medical treatments is worth bearing in mind when asking why people came to the hospital. 'Proof of efficacy is less important than efficacy itself. New ideas can be adopted not because they are logical or even consistent, but because they appear to work', as Murray Last argues. ${ }^{110}$ For this reason, Gabonese continued to consult local Ngangas, but also took advantage of newly available hospital facilities. ${ }^{111} \mathrm{Head}-$ rick argues that the case of Schweitzer's hospital proves how perceptively patients could evaluate the quality of care that they received and their chances of recovery. ${ }^{112}$ Emane agrees, contending that no Gabonese expected Schweitzer and his staff to 'treat everything', but rather that they would be able to cure a specific set of diseases. ${ }^{113}$ In this regard, it is important to note that when I enquired about 'traditional medicine', almost all of my informants, African or European, strongly denied the existence of any alternative practices within the hospital's premises. This absence is similarly apparent in the written sources. Occasional cases, however, illustrate that medical pluralism was practiced.

Furthermore, medical options shared similarities in how they dealt with the sick, as is evident in specific examples throughout this book: autopsies resemble surgeries; a pregnant woman's voyage away from her village may lead to either her mother's home or a hospital; herbal remedies are applied like biomedical drugs against infectious diseases, and community care for the mentally ill is found in hospitals and villages alike.

A brief comparison between hospital treatments and those offered by Ombwiri serves to further illustrate this point. For Myene speakers, Imbwiri were 'fairies', 'ghosts', or 'functional spirits' that resembled humans. ${ }^{114}$ They were associated with a specific location and could cause physical diseases. They could

\footnotetext{
107 Emane, Docteur Schweitzer: une icône africaine, 65-69.

108 Schweitzer, Zwischen Wasser und Urwald, 36. Schweitzer's spelling of the term is 'Oganga'.

109 Munz, Albert Schweitzer im Gedächtnis der Afrikaner und in meiner Erinnerung, 216.

110 Last, 'Non-Western Concepts of Disease', 648.

111 Mabika, 'Médicalisation de l'Afrique centrale', 417.

112 Headrick, Colonialism, Health and Illness in French Equatorial Africa, 401.

113 Emane, Docteur Schweitzer: une icône africaine, 128.

114 Swiderski, 'L'Ombwiri', 128-29.
} 
be pacified through the Ombwiri ceremony, which was widely practiced among most ethnic groups of the region by the 1960s. This ceremony, which has frequently been referred to as the 'hospital' by scholars and their informants, was clearly therapeutic in scope. ${ }^{115}$ Its leaders, the majority of whom were women, were usually former patients. It was not unusual for nurses from a biomedical hospital to participate. The ritual had to be paid. Purification occurred in a very tangible manner in which cleanliness was paramount: the diseased was bathed; freshly laundered sheets were spread on the walls and pillars; and purgatives were administered, sometimes forcibly, including psychedelic substances from iboga and herbal medication. Ombwiri also targeted the health of the whole family; relatives were thus present during the ceremony. ${ }^{116}$ Parallels to practices in biomedical hospitals in general and Schweitzer's hospital in particular are immediately identifiable: African biomedical personnel had often first stayed as patients, hygiene was important in most units, and family members were allowed to accompany patients. The degree of interaction between these two and other healing institutions would merit further research, but is beyond the scope of this study.

\section{Staff from Europe: Clear Guidelines and Flexible Duties}

In August 1935, Schweitzer described a typical day at his hospital in his Letters from Lambaréné Hospital, regular leaflets he compiled for his supporters in Europe. ${ }^{117}$ This very detailed account offers a window into what he pictured as the ideal organizational structure for his institution. While clearly focused on the role of European staff, his discussion of their various duties provides a useful overview of the frequency of certain diseases and the workload in different wards.

Employees from Europe usually committed themselves to staying a term of two and a half years. At the time of Schweitzer's account, three doctors were practicing at the hospital; this had not always been the case, however, as for some months in 1933 only one physician had been present. ${ }^{118}$ Schweitzer himself did not practice anymore. One doctor was responsible for European

\footnotetext{
115 Fernandez, Bwiti, 595; Mary, 'L'alternative de la vision et de la possession', 299; Swiderski, 'L'Ombwiri', 130.

116 Fernandez, Bwiti, 595-99; Swiderski, 'L'Ombwiri'.

117 The nurse Siefert also offers a detailed description, but focuses more on Schweitzer. Any further discrepancies between her account and that of Schweitzer's are minor. See: Siefert, Meine Arbeitsjahre in Lambarene 1933-1935, 56-60.

118 Ibid., 56. See also 'Statistique de l'Hôpital 1933', L - A - S2, AMs.
} 
patients, psychiatric patients, urological cases and, most importantly, performing the main surgical work and keeping the pharmacy in order. Another doctor focused on cases of leprosy, sleeping sickness, tuberculosis and foot ulcers, while additionally overseeing women in childbirth and patients requiring regular injections. The third doctor also carried out surgery and supervised all bandaging procedures and dysentery patients. ${ }^{119}$ These roles were not fixed, but flexibly assigned to the doctors present according to their abilities and preferences and in view of the diseases that were most prevalent at any given time. A close reading of Schweitzer's account reveals that the doctors' roles varied even within the same week. For example, each doctor was responsible for the pre-breakfast rounds on different days. ${ }^{120}$

According to Schweitzer's ideal schedule, the day would continue with consultations and new registrations from 8 a.m. ${ }^{121}$ Each doctor, who would be accompanied by an interpreter, would summon their patients from the outside waiting area. A compulsory one-hour siesta followed the lunch break. Afternoons were ideally reserved to treat critically ill patients. Doctors were encouraged to discuss their work extensively amongst themselves and thus, when possible, joined their colleagues on their evening rounds. At 7 p.m. all Europeans dined together, after which prayers were held. One and a half hours later, the evening bell signaled silence for the rest of the night. This brief overview suggests that a collegial atmosphere and mutual understanding among staff, what we call 'Lambaréné Spirit', was essential. ${ }^{122}$

All European nurses were female until Schweitzer's death. From 1925 to 1965 , roughly 20 percent of all physicians were women. ${ }^{123}$ Initially, Schweitzer considered European women to be unfit for equatorial conditions, but soon changed his mind. He claimed that 'Blacks are at their command'; they were 'under the spell of female kindness', which nurses 'united with male knowledge'. Hence, they served them 'out of a desire to demonstrate their dedication to them.'.124

119 Schweitzer, 'Briefe aus dem Lambarene Spital November 1935', 5.

120 Ibid., 2.

121 For the whole account, see: Schweitzer, 'Briefe aus dem Lambarene Spital November 1935'.

122 Mabika Ognandzi, Steinke, and Zumthurm, Schweitzer's Lambaréné: A Hospital in Colonial Africa.

123 These rather tentative calculations and observations are based on the following list of employees. However, this list is undoubtedly imprecise and incomplete: http:// schweitzer.org/2012/de/lambarene/mitarbeiter-1913-1965 (This site no longer exists. The author possesses a copy of the list). The table lists forty-one doctors for the period from 1925 to 1965 .

124 Albert Schweitzer, 'Le secours médical aux colonies', Revue des Deux Mondes September 1931. Cited in: Sorg, Schweitzer, le médecin, 34. 
Schweitzer's confidence in his female staff was so great that, during the dry season of 1931, Dr. Anna Schmitz and Emma Haussknecht were sent on a 'medical excursion in jungle and savannah'. Guided by ten African porters, they visited approximately 200 villages, covering 300 kilometers on water and 800 kilometers on foot over a period of two months. ${ }^{125}$ Swiss doctor Karl Hediger went on a similar but smaller tour in 1929, treating roughly one hundred patients. ${ }^{126}$ Schweitzer had long envisioned having an itinerant doctor on constant duty in the surrounding regions in order to see patients in their villages. ${ }^{127}$ However, besides the occasional visit on lumber camps and mission stations these plans were never realized, with those tours remaining exceptions.

Three of the eight nurses performed only medical duties. Flexibility and adherence to the Lambaréné Spirit were expected from nurses too. One worked in the operating theater, sterilized dressings, and monitored the African washwomen. A second nurse also assisted the surgeons, bandaged patients who had undergone operations, and cared for European patients. A third nurse worked in the consultation room, distributed medication, and was responsible for the care of mothers and newborn children as well as critically ill patients across all quarters. A fourth nurse dressed ulcers, cared for psychiatric patients, supervised African women who manufactured palm oil, and was in charge of the purchase and distribution of food. The other four nurses were responsible for housekeeping and food preparation, including one who mainly oversaw workers in maintaining the plantations. ${ }^{128}$

The same individuals could take on more than one of these roles during their time in Lambaréné. Throughout the study period, staff had to be highly flexible, both within and outside of the medical domain. The nurse Gertrud Koch, for example, was disappointed when she was assigned the role of working in the kitchen in $1929 .{ }^{129}$ Later, she received the additional task of looking after European patients. This must have satisfied her as she returned to Lambaréné four times until 1952. ${ }^{130}$ The nurse Emma Ott arrived in January 1937. In addition to kitchen and gardening duties, she also had to take care of the chickens and ducks. She was one of the few staff to voice dissatisfaction with her role. 'Because I don't know anything about it, I have no love for it', she wrote. ${ }^{131}$

\footnotetext{
125 Schweitzer, 'Briefe aus dem Lambarene Spital November 1931'. This volume is dedicated solely to the tour.

126 Hediger to Schweitzer, 9 August 1929, AMs.

127 Schweitzer, 'Neues von Albert Schweitzer März 1925', 2.

128 Schweitzer, 'Briefe aus dem Lambarene Spital November 1935', 6.

129 Koch, 'Lieber grand Docteur!', 165.

130 Schweitzer, 'Briefe aus dem Lambarene Spital März 1930', 4.

131 Ott, 'Kleine Steine im grossen Mosaik', 106.
} 
It is important to underline once again that this organizational structure was an ideal. In practice, the hospital was run on a much more flexible basis, and the composition and number of personnel varied greatly. For the staff, flexibility remained one of Schweitzer's most persistent demands. In Chapter 3, I discuss how this influenced the recruitment process for both African and European obstetric personnel. In general, however, there was a trend towards specialization at the hospital. In the 196os, nurses were tasked with a less diverse range of duties and were responsible for more specialized units, such as psychiatry or pediatrics, which until the late 1950s had often been one of the many responsibilities for an individual nurse. However, personnel still had to display a high degree of flexibility. They were often moved around between different roles and had to be willing to work in non-medical domains.

Before they started their work, new staff were rather informally shown around the different wards and given a taste of the various tasks that needed to be completed at the hospital, a process that could last up to a week. ${ }^{132}$ They were then introduced to their specific role, usually by their predecessors. ${ }^{133}$ Thereafter, they enjoyed considerable freedom in the performance of their duties. They could improve their wards according to their own ideas and were normally successful in acquiring any materials that they thought were missing if they showed some initiative. Allusions to this relatively independent working environment emerged more frequently in the interviews than in the written sources.

The Swiss nurses Marianne Stocker and Hedwig Schnee are only two of many examples that illustrate the above points. At the beginning of her stay in 1961, Stocker, who was trained in pediatrics, was given the job of spring-cleaning the pharmacy and distributing donated clothes. Then, she was occupied for five days with repacking multivitamins sent from the USA. ${ }^{134}$ Even after she began her regular duty of nursing children, she was still responsible for sewing curtains ${ }^{135}$ and continued to distribute food three times per week for some time. ${ }^{136}$ She was also supposed to assist the surgeons and care for patients who had recently undergone operations, tasks which she refused because she did not feel sufficiently qualified. ${ }^{137}$ Stocker initiated pre- and postnatal counselling during her second stay, which she commenced in $1965 .{ }^{138}$

\footnotetext{
132 Munz-Boddingius, 'Meine Chance und Freude, Hebamme in Lambarene gewesen zu sein', 65; Group Interview Speicherschwendi.

133 Group Interview Speicherschwendi.

134 Stocker, 'Diary 1961-63', 12-16.

135 Ibid., 51.

136 Ibid., 36 .

137 Ibid., 50.

138 Interview Marianne Stocker.
} 
Schnee was relocated frequently during her almost three-year-long stay and performed numerous tasks. She administered injections, distributed and manufactured medications, and assisted with anesthetics. Schnee helped to establish a ward comparable to an intensive care unit, which they named 'Case Japonais' to honor the donors from Japan. Schnee monitored patients in this ward and even buried deceased ones. ${ }^{139}$ She acquired cortisone for the Case Japonais for patients suffering from allergic reactions. When she required infusion stands or a cupboard for storing drugs, Schnee recalled simply going to the carpenter and ordering them there without asking for anyone's permission. ${ }^{140}$

European staff followed different trajectories in coming to work in Lambaréné. Walter Munz answered a job advertisement in the 'Schweizerische Ärztezeitung', the professional magazine for physicans. ${ }^{141} \mathrm{He}$ was interviewed to Basel by Dr. Hermann Baur, then president of the Swiss association supporting the hospital. As all staff did, African and European alike, Munz received a modest salary as well as free board and lodging. ${ }^{142}$ Stocker wrote to the same association, with which she was familiar through her mother, who used to donate bedding and similar items to it. Her contact person there was Anita Dinner, who sent her to Gunsbach, where her state of health was examined and she was interviewed by Emmy Martin, Schweitzer's administrator in Europe. ${ }^{143}$ Another option for finding work at the hospital was through acquaintances; Schnee, for example, was invited by Munz. ${ }^{144}$ These brief examples highlight the importance of Schweitzer's personal network of people he trusted. They served as his gatekeepers in Europe. They ensured that a candidate was not only in good health and sufficiently qualified, but also compatible with the 'Lambaréné Spirit', which demanded, among other things, that processes and people at had to be simple and natural, proficient and undemanding. ${ }^{145}$

When interviewed, nurses fondly recalled their often scarce free time. During communal dinner, a wide range of issues would be discussed, including medical matters. ${ }^{146}$ The seating arrangement represented the hospital hierarchy: towards the end of their stay, staff sat closer to Schweitzer and his most

\footnotetext{
139 Interview Hedwig Schnee, Speicherschwendi.

140 Ibid.

141 Interview Munz and Munz. According to Munz, desired qualifications were two years of surgical experience, fluency in French, unmarried status, and a commitment to work for 32 months. The original advertisement could not be found.

142 Even among the same group, i.e. African assistants, not everyone received the same salary.

143 Interview Marianne Stocker.

144 Group Interview Speicherschwendi.

145 Mabika Ognandzi, Steinke, and Zumthurm, Schweitzer's Lambaréné: A Hospital in Colonial Africa.

146 Interview Ursula Bunch.
} 
loyal personnel, who might offer their spot to important visitors. ${ }^{147}$ Africans were present only as servants. ${ }^{148}$ Staff members were generally satisfied with the food that they received; the fruit and vegetables from the hospital plantations are a happy memory. ${ }^{149}$ When everyone had finished eating, Schweitzer would read from the Bible and play the piano, while staff members would sing together. Attendance at these gatherings was voluntary, but normally everyone participated. ${ }^{150}$ Thereafter, there was time for staff members to write letters, converse with each other in their rooms, or, less frequently, to listen to records. ${ }^{151}$ In general, former staff members described and remembered the communal aspects of life at the hospital in a positive light, although some complaints about a lack of privacy were raised. ${ }^{152}$

Typically, each member of staff enjoyed a day off on every second Sunday. On this free day, they would often go on an excursion. They ventured, for example, to one of the nearby mission stations to spend time with fellow Europeans and play pétanque. ${ }^{153}$ Several interviewees also remembered visiting neighboring villages, where they were joyfully welcomed by former patients or employees. Pirogues were bought or rented and rowers hired for these journeys. According to some nurses, Schweitzer did not approve of such trips or even prohibited them. ${ }^{154}$ However, the ban was not too strictly enforced. ${ }^{155}$ Schweitzer also discouraged swimming in the river, but this did not prevent everyone from doing so. ${ }^{156}$ Stocker wrote in her diary that she stole away one Saturday to attend a 'dance' in nearby Adouma. Other nurses reported similar occurrences. ${ }^{157}$ This partly contradicts the observation made by Fernandez on the lives of European employees at the hospital at the time, namely that the majority 'had only left the hospital to go to Lambaréné town and then only

147 Zumthurm, 'Food at the Albert Schweitzer Hospital'.

148 Barthélemy, Wie ich Lambarene erlebte, 25; Fernandez, "The Sound of Bells in a Christian Country', 543; Füllemann, 'Aus jüngster Zeit', 162.

149 Group Interview Speicherschwendi; Interview Ursula Bunch. During the dry season, a wide variety of European vegetables were grown there. An important component of every breakfast was quinine.

150 Group Interview Speicherschwendi; Interview Ursula Bunch; Interview Munz and Munz.

$15^{1}$ Interview Ursula Bunch; Interview Marianne Stocker; Interview Hedwig Schnee.

152 Interview Elisabeth Anderegg; Interview Ursula Bunch.

153 Interview Elisabeth Anderegg.

154 Ibid.; Group Interview Speicherschwendi.

155 During her time at the hospital, Schweitzers daughter Rhena lent a boat to a newlywed couple and Dr. Müller owned a motorboat. See: Interview Ursula Bunch.

${ }_{15}$ Interview Elisabeth Anderegg; Interview Marianne Stocker.

157 Stocker, 'Diary 1961-63', 18; Interview Elisabeth Anderegg; Group Interview Speicherschwendi. See also Chapter 5 . 
once or twice. They were eager to hear of the life of their patients in the village, which they knew next to nothing about'.158

\section{African Staff: Versatile Training and Reliable Service}

Typically, nurses who were new to the job were introduced to their roles by African auxiliaries who had long been stationed in their respective wards; nevertheless, most nurses report that they themselves were also responsible for training new African personnel. ${ }^{159}$ African auxiliaries had worked for Schweitzer since his initial arrival in Lambaréné. In his 1935 report, he only wrote that there were eight auxiliaries, who were assigned their tasks for the day by a nurse before breakfast. ${ }^{160}$ Four years earlier, he had listed five: Mendoume and N'Gema dressed ulcers and cared for patients with dysentery or mental illnesses; Boulingui for whom Schweitzer was full of praise, had been employed in the surgical service since 1924; Arthur looked after the critically ill; and Nyama worked in the consultation room, administered injections, and prepared the necessary solutions. ${ }^{161}$ In 1938 , Schweitzer employed twelve Africans, including one woman. ${ }^{162}$ They were all under the constant supervision of a doctor or, occasionally, a nurse. ${ }^{163}$ Some of these auxiliaries were in almost lifelong service at the hospital. Jeannette Siefert, who had worked as a nurse at the hospital in the 1930s, visited it again in 1960 and noted that Nyama and Mendoume were still employed there. ${ }^{164}$

The story of Joseph Ndolo, as told by himself in a book edited by Munz, provides an idea of an auxiliary's responsibilities. ${ }^{165}$ It remains one of the few written accounts by African personnel or patients. Ndolo, son of a 'healer', began working in 1954 at the age of twenty-two and remained in his position until 1987. Unlike most of his peers, he did not have any relatives who were already employed there. ${ }^{166}$ He showed initiative and convinced Schweitzer to engage

\footnotetext{
158 Fernandez, 'The Sound of Bells in a Christian Country', 542f.

159 Group Interview Speicherschwendi,; Interview Elisabeth Anderegg; Stocker, 'Diary 1961-63'.

16o Schweitzer, 'Briefe aus dem Lambarene Spital November 1935', 2, 8.

161 Schweitzer, 'Briefe aus dem Lambarene Spital Pfingsten 1931', 9.

162 Schweitzer to Morel, 28 August 1938. Published in: Bähr, Albert Schweitzer: Leben, Werk und Denken, 153 .

163 Schweitzer, 'Briefe aus dem Lambarene Spital November 1935', 5 .

164 Siefert, Meine Arbeitsjahre in Lambarene 1933-1935, 180.

165 Munz, Albert Schweitzer im Gedächtnis der Afrikaner und in meiner Erinnerung, 97-103.

166 On the recruitment of personnel, see Chapter 3.
} 
him. At first, his duties included packing drugs, cleaning and sterilizing medical instruments, and distributing medication. After three months, Ndolo was given the responsibility of performing laboratory analyses alongside Joseph Bissangoy, who had been in the role for years, and was also taught to give injections. These remained Ndolo's two primary tasks until his retirement. ${ }^{167}$

Ndolo lists his twenty-nine colleagues, as of 1964, by name and role. This allows for a tentative comparison with auxiliaries' responsibilities in the $1930 \mathrm{~s}$. In 1964, five of the auxiliaries were interpreters, two more than thirty years earlier. Seven assisted the surgeons and four cared for patients recovering from operations, whereas in the 1930s Boulingui alone had been responsible for both tasks. In 1931, two auxiliaries were supposed to share the task of dressing ulcers and caring for patients with dysentery or mental illness; over thirty years later, only Marcel Poungui was tasked with bandaging, Jean Mendoume and Samuel Lane looked after patients with mental illness, and dysentery ceased to have been a constant threat. By 1964, Nyama had received a colleague to assist the nurse in the injection room, which Schnee compared to a chicken coop annexed to the Grande Pharmacie. She claims to have administered the shots herself, while Nyama had been reported to do them in the 1930s. ${ }^{168}$ Besides Evangéline Ebako and Véronique Mabwe in the maternity ward, there were only two other female auxiliaries in 1964: Annemarie Babalou in the operating theater and Mama Hélène, who assisted Alain Douviogou in the leprosy settlement. Ndolo additionally mentions Noel Ndoung who distributed medication, Kwamba who maintained the fire used for sterilizing instruments, and Pierre Ndounge who was responsible for preparing beds and food. ${ }^{169}$ The auxiliaries did not occupy leading positions in these domains. Instead, they performed tasks that in European hospitals would have been fulfilled by the nurses supervising them in Lambaréné. The actual degree of responsibility and autonomy that these auxiliaries enjoyed differed considerably, as will become clear in the analyses of the different wards.

In 1964, Ndolo initiated informal anatomical and technical training for African auxiliaries, which was given by the European doctors. ${ }^{170}$ The on-the-job training that the auxiliaries had had hitherto received had already been the subject of much criticism during Schweitzer's lifetime. Dr. Louis Paul Aujoulat, who would later open a hospital in Cameroon, first visited Lambaréné in 1935. At the time, he advised Schweitzer to open a school to train African nurses and,

167 Munz, Albert Schweitzer im Gedächtnis der Afrikaner und in meiner Erinnerung, 97-103.

168 Interview Hedwig Schnee.

169 Munz, Albert Schweitzer im Gedächtnis der Afrikaner und in meiner Erinnerung, 100.

170 Ibid., 100-102. 
at a later stage, doctors too. He recalled Schweitzer's reaction: 'Schweitzer listened to me with infinite patience; he contradicted me, of course, and in the end, he interrupted me in my enthusiasm and said: "Have you come here to seek advice or to give it to me?"'171 Dr. Clement Chesterman made the same suggestion almost twenty years later. Schweitzer replied, more concretely now, that he had too many other things to do and that he considered this to be the government's responsibility. ${ }^{172}$

Several of my Gabonese interviewees considered the training that their parents or grandparents received at the hospital to have been highly valuable. They did not differentiate between European and African personnel, using the French 'infirmier' or 'infirmière' for any nurse. They insisted that Schweitzer 'trained' and 'formed' his own nurses. ${ }^{173}$

\section{$7 \quad$ Staff in Comparison}

Historical research on African medical assistants in neighboring Cameroon, for example, has emphasized their peculiar position. On the one hand, they were suspected to benefit from 'the extraction of body substances' or saw themselves confronted with witchcraft accusations; on the other hand, they 'drew considerable social prestige and economic opportunities' from their positions. ${ }^{174}$ In any case, they held a central role as translators of biomedical understandings of health and disease and as mediators between patients and doctors. Our case shows that even beyond these issues they were crucial in the daily routines of the hospital.

In China and India, mission stations started to train local Christian converts to staff their hospitals in the late nineteenth century. ${ }^{175}$ In South Africa, formal nursing training for Africans was initiated in 1906, based on previous

171 Aujoulat, 'Albert Schweitzer, médecin de brousse', 222-23. For more on Aujoulat, see: Lachenal and Taithe, 'Une généalogie missionnaire et coloniale de l'humanitaire'.

172 Schweitzer to Chesterman, 24 March 1953, AMs. During the 1920s, Chesterman had worked for the Baptist Missionary Society in Yakusu near todays Kinsangani in the DRC. He was in constant contact with Schweitzer and would later become a director of the supporting foundation of the hospital in England. For more on his time in the Congo, see: Hunt, A Colonial Lexicon.

173 Interview Jacques Boucah; Interview Léontine Nsowe; Interview Jacques-Adrien Rolagho.

174 Lachenal et al., 'Neglected Actors in Neglected Tropical Diseases Research', 3, 10. Their analysis draws from the research of Cameroonian historian Wang Sonné, whose work I was not able to access.

175 Hardimann, 'The Mission Hospital', 207-9. 
experiences in what is today Malawi. ${ }^{176}$ In colonial Uganda, a medical service consisting of African officers was established in 1914. ${ }^{177}$ The French government medical school in Dakar, Senegal, opened its doors to Africans two years later. ${ }^{178}$ The British in colonial Ghana had established a training program for Africans by $1920 .{ }^{179}$ Many of these programs would lead to a recognized diploma. It remains to be examined in greater detail, however, what exactly was taught in these programs and how they differed from Schweitzer's on-the-job approach to training. Rita Headrick writes that in the case of training programs for African nurses in AEF 'doctors, the health reports, and the nurses themselves all agreed that, with few exceptions, nurses were badly trained and incompetent at all but a few tasks.'. 180

European nurses, numerous and prominent in our case, have received increasing research attention. It has been argued that globally their qualifications tended to be assessed 'in terms of character rather than intellect'. ${ }^{181}$ This was especially applicable in the colonies, ${ }^{182}$ as indeed can be observed at Schweitzer's hospital. Nurses aspired to serve in the colonies due to the desire for more personal and financial independence, and greater professional responsibilities. ${ }^{183}$ Catholic missionary nurses in particular were further driven by their faith and the wish to 'make a difference in the world by moving beyond the domestic realm'. ${ }^{184}$ Similar motivations prompted women to seek employment at the Albert Schweitzer Hospital.

Colonial doctors have been more thoroughly researched. For example, Anna Crozier has published a detailed study on British doctors in colonial East Africa. As in other colonial services, interpersonal networks, mutual favors and patronage formed important elements of the recruitment process, as did the assessment of a prospective doctor's character. ${ }^{185}$ Doctors maintained a distinct

\footnotetext{
176 Digby, Diversity and Division in Medicine, 243-44; Parle and Noble, 'The Hospital Was Just Like a Home', 192-93.

177 Lyons, 'The Power to Heal', 206.

178 Cole, 'Engendering Health', 119.

179 Patterson, Health in Colonial Ghana, 16-17.

$18 \mathrm{o}$ Headrick, Colonialism, Health and Illness in French Equatorial Africa, 251.

181 Rafferty, 'Nurses', 520.

182 Headrick, Colonialism, Health and Illness in French Equatorial Africa, 247; Nestel, '(Ad) Ministering Angels', 262, 265 .

183 Nestel, '(Ad) Ministering Angels', 263; Schweig, Weltliche Krankenpflege in den deutschen Kolonien Afrikas, 14-15, 37.

184 Wall, Into Africa, 30.

185 Crozier, Practising Colonial Medicine, 32.
} 
group culture, ${ }^{186}$ but had diverse career motivations. ${ }^{187}$ Typically, they were politically conservative and of upper-class origin, but enjoyed a lower social and financial status than other colonial officials. ${ }^{188}$ Almost all were men: less than 3 percent of all physicians having practiced in East Africa prior to World War Two were women. ${ }^{189}$ Headrick notes a similar gender imbalance in the case of AEF. ${ }^{190}$ Africa was considered particularly unsuited for women, an assessment with which Schweitzer apparently did not agree. In India, in contrast, more than half of all medical missionaries in 1900 were female. ${ }^{191}$

Mabika underlines the diverse class origin of doctors in Gabon. Those he interviewed were motivated primarily by the sense of participating in a 'civilizing mission' or a desire to serve France, but scientific curiosity and aspiration, as well as a yearning for adventure, were also mentioned. ${ }^{192}$ Headrick highlights the 'esprit de corps' shared by doctors in AEF. She argues that this sense of fellowship was particularly well articulated there due to the low standing of a colony in which 'the administrators were newcomers, or mediocre, or known failures, and where most missionary doctors were more interested in religion than in medicine.'193 Schweitzer had created an equivalent at his hospital with the 'Lambaréné Spirit' already referred to.

According to Headrick, the government doctors in AEF were usually young, of low social class, and prone to the worrying changes in personality so often described in novels on Europeans living in colonial settings. ${ }^{194}$ Balandier's government doctor in Lambaréné, who has been introduced in the Introduction, appears to have undergone a similar transformation. He was sent home after imitating William Tell by shooting empty water bottles off the heads of his servants. Balandier concedes that this story sounds extraordinary, but argues

186 Ibid., 119.

187 A doctor's salary in East Africa was moderate, but comfortable; entry conditions were easy; and the social prestige and benefits were considerable. The region offered a promise of adventure in the form of hunting and other leisure activities. The East African climate was considered comparatively healthy. Many doctors already had a mentor in the area or were following the precedent of a friend or relative. Others were motivated by religion or humanitarianism. Professional motivations included the opportunity to become an expert in an emerging field or acquire knowledge in other natural sciences; the diverse nature of a local doctor's duties; and the chance to gain personal and professional independence. See: ibid., 47-68.

188 Ibid., 106.

189 Ibid., 98.

190 Headrick, Colonialism, Health and Illness in French Equatorial Africa, 261.

191 Hardiman, Missionaries and Their Medicine, 141.

192 Mabika Ognandzi, Médicaliser l'Afrique, ${ }_{153}^{-56 .}$

193 Headrick, Colonialism, Health and Illness in French Equatorial Africa, 240.

194 Ibid., 45-50. 
that it was indicative of Gabon's particular 'natural and human milieu'. This, according to him, differed significantly from that of the neighboring French Congo, the other colony that he had researched:

It shows how quickly Gabon can use up the men at its service. It takes a particularly well-armed personality, or powerful material interests, to rise up against a natural and human milieu that possesses an astonishing capacity for annihilation and also has the benefit of being oversized and excessive. ${ }^{195}$

In this light, Schweitzer's enduring positive attitude and his quasi-immunity to tropical diseases are remarkable. Such self-control was strongly connected to 'other-control', as Johannes Fabian reminds us. ${ }^{196}$ This partly explains Schweitzer's careful selection of hospital personnel and strict organization of their busy working lives. He was successful in minimizing Gabon's negative effects, as described by Balandier, on his staff. Stories similar to that of the government doctor at Lambaréné have not emanated from the Albert Schweitzer Hospital. Although most of the European staff would ultimately complain of tiredness, especially towards the end of their stay, accounts of them drifting into a state of mental decline similar to those described by Balandier or Joseph Conrad are absent.

\section{Infrastructure: Necessity and Maintenance}

Table 1 summarizes the growth of the hospital. The most significant period of growth occurred in the late 1950s, when, alongside an influx of patients, the number of staff rose appreciably. Most notable is the increase in African auxiliaries. The presence of more patients and staff at the hospital invariably required the construction of more buildings. By 1965, the main hospital premises

\footnotetext{
195 Balandier, Afrique ambiguë, 219.

196 Fabian described nineteenth-century explorers in Central Africa as follows: "Typically, the traveller was depicted as an individual, often solitary, agent, full in control of himself and others. Psychologically, morally, and intellectually, he was equipped to carry out the assigned task, unless impeded or prevented by persons, events, or conditions beyond his control. Self-control required "other-control", which above all meant maintaining distance from the country to be explored and its people'. Fabian, Out of Our Minds, 7. This description offers undoubted parallels to the way in which Schweitzer understood his role in Lambaréné.
} 
TABLE 1 The growth of the hospital

\begin{tabular}{lcl}
\hline & Early 1930s to mid-1950s & 1960s \\
\hline Inpatients & $150-250$ & $\begin{array}{l}290-390(+ \text { ca. } 150 \\
\text { leprosy patients })\end{array}$ \\
Doctors & $3-4$ & $4-6$ \\
Nurses & $7-8$ & $11-16$ \\
Auxiliaries & $6-9$ & $16-30$ \\
Buildings & $20-30$ & ca. 70 \\
\hline
\end{tabular}

contained as many as seventy structures, ${ }^{197}$ as opposed to twenty to thirty in the 1930s. A number of new wards were established in the 196os, such as a building specifically for children or an intensive care unit. ${ }^{198}$

After the hospital's relocation in 1927, Schweitzer left for a longer stay in Europe to accumulate more substantial funds, returning in early 1930. The nurse Marie Woytt-Secretan, who accompanied him on his return, recalled that the hospital consisted of seven buildings at the time. When she left Lambaréné in 1932, she counted thirty-two buildings, although she may have included annexes and other smaller structures. ${ }^{199}$ In his 1933 annual report, Schweitzer listed sixteen buildings plus 'buildings necessary to house indigenous staff'. ${ }^{200}$ The spatial core of the hospital was the Grande Pharmacie, a large building of 180 square meters that contained an operating theater, a consultation room, a bandaging room, a laboratory, a washhouse, a room for urology, and a small pharmacy for storing and one for producing basic medication. European patients were housed in their own building, which consisted of six rooms, each with two beds. Africans stayed in five different buildings with pallet beds, which housed a total of 216 patients. Unlike the majority of the other sleeping quarters, their windows were not equipped with mosquito nets. ${ }^{201}$ There were also two storehouses, two buildings for European personnel, and

197 As estimated by: Harris, 'The Allure of Albert Schweitzer', 816. A rough map produced in 1966 suggests a similar number of buildings. See: 'Lambarene 1966 - Statistiques', L - A S3, AMs.

198 Group Interview Speicherschwendi.

199 Woytt-Secretan, 'Souvenirs d'une infirmière', 32.

200 'Statistiques de l'Hôpital 1933', L - A - S2, AMs.

201 Schweitzer, 'Briefe aus dem Lambarene Spital November 1935', 15. 
various quarters to isolate patients suffering from leprosy and other contagious diseases or mental disorders.

During the early 1930s, the hospital was modernized in various ways. In 1935, a European patient donated a powerful petroleum lamp that made it possible for doctors to perform emergency surgeries at night, a frequent enough occurrence. ${ }^{202}$ In November 1933, an engine-driven refrigerator, which had been donated by an Alsatian doctor, was installed. They would keep certain drugs therein. In addition, Schweitzer was happy to report that the hospital could now store leftover food and further rejoiced that 'only those who have lived in equatorial primeval forest lowlands can appreciate what refreshment the glass of cool water, which we now receive at 10 a.m. and at 4 p.m., means to us doctors and nurses.. 203

Water supply was a major concern throughout the study period. Pumps, first installed in 1927 , frequently did not work and often had to be replaced. ${ }^{204}$ The reservoir, built four years later, only provided water during the rainy season. ${ }^{205}$ Recurring reports tell of patients and staff who were forced to drink water from the river. ${ }^{206}$ This was a significant health concern, as will be shown in Chapter 4. In the 1960 s, staff was still boiling river water for human consumption. ${ }^{207}$

In the early 196os, after Gabon had gained its independence, criticism of Schweitzer's work in Lambaréné increased, as we have seen in the Introduction. The main critique was that the hospital still operated from a backward ideological perspective and was insufficiently modern in terms of its medical equipment and practices, issues that Gabonese evaluated much less disapprovingly. ${ }^{208}$ However, many European visitors and staff who returned to the hospital on more than one occasion commented on its stagnation. When Aujoulat returned to Lambaréné in 1952, seventeen years after his first visit, he noticed no changes. Indeed, his only criticism of Schweitzer was that he did

202 Schweitzer, 'Briefe aus dem Lambarene Spital Juni 1935', 4. The introduction of new lighting and other technologies is a central focus of Chapter 2.

203 Schweitzer, 'Briefe aus dem Lambarene Spital Februar 1934', 8.

204 Schweitzer, 'Briefe aus dem Lambarene Spital Pfingsten 1931', 3.

205 Haussknecht, Emma Haussknecht, 1895-1956, 88.

206 Schweitzer, 'Briefe aus dem Lambarene Spital März 1938', 6; Interview Hedwig Schnee; Haussknecht, Emma Haussknecht, 1895-1956, 88.

207 Anderegg recalled that each drop of river water was boiled. See: Interview Elisabeth Anderegg. Margrith Stark-Bernhard, who was tasked with domestic duties from 1962 to 1964, wrote that one of her daily responsibilities was to supervise the boiling of river water. Thereafter, the water was filtered and then offered to the staff as drinking water. See: Stark-Bernhard, 'Waschfrauen, Büglerinnen, Schneider und Matratzenmacher', 28.

208 Emane, Docteur Schweitzer: une icône africaine, 32, 92-93. 
not attempt to adapt to changing circumstances in the wider world. ${ }^{209}$ Three years later, a visiting surgeon from South Africa reported that 'the consulting or outpatient department is exactly as it was built over 30 years ago, and looks rather like a film setting of the old fashioned wild-west saloons.'210 Dr. Markus Lauterburg-Bonjour, who in 1925 was the third doctor to arrive at the hospital, returned in 1961. Stocker noted his casual observation in her diary: 'Actually nothing has changed [...] there are more people, more houses, but otherwise it is not much different'. Stocker was undecided as to whether this should be understood as a compliment. ${ }^{211}$

A number of visitors commented on the lack of up-to-date equipment at the hospital. Fernandez argued that 'Schweitzer's resistance to modernization (was) a resistance very likely to impersonal organization' ${ }^{212}$ The Alsatian organist Edouard Nies-Berger, who stayed in Lambaréné in the early 1960 s while working with Schweitzer on a publication on J.S. Bach, is more outspoken. According to him, Schweitzer's 'well-known obstinacy had become a curse', and his 'reluctance to cope with modern needs' was shared by many of his longtime collaborators. ${ }^{213}$ Such assessments surely depend on the observer's point of view and Schweitzer's standing certainly provoked its own criticism. Nevertheless, the persistence and regularity of these complaints and comments, and the fact that they came from visitors and collaborators alike, demonstrate that a conservative atmosphere pervaded most parts of the hospital.

Electricity was restricted to the operating theater and the radiology room. This power was produced by a diesel generator, a complex machine that was installed in 1951. It had to be turned on by the hospital mechanic, who needed to be ready to do so at any time in case of emergencies. ${ }^{214}$ The hospital could have been connected to the public power supply network towards the end of the 1950s, but Schweitzer refused to allow this, possibly because he feared a loss of independence. ${ }^{215}$

\footnotetext{
209 Aujoulat, 'Albert Schweitzer, médecin de brousse', 223-24.

210 Penn, 'A Visit to Albert Schweitzer', 164.

211 Stocker, 'Diary 1961-63', 24.

212 Fernandez, 'The Sound of Bells in a Christian Country', 557. Italics mine.

213 Nies-Berger, Albert Schweitzer as I Knew Him, 108. Here, Nies-Berger explicitly identifies Mathilde Kottmann and Ali Silver. The former offered her services to Schweitzer as a midwife in 1923, while the latter arrived as a nurse after World War Two. Both rose in the ranks to take responsibility for administrative tasks and enjoyed a high position in the hospital hierarchy by 1960 .

214 Interview Munz and Munz; Interview Elisabeth Anderegg; Interview Ursula Bunch.

215 Scholl, Von der Ehrfurcht vor dem Leben zur transkulturellen Solidarität, 103.
} 
X-ray equipment was installed in 1954 after Emeric Percy, a Hungarian doctor who served two terms in the 1950s, had convinced Schweitzer to buy it, because it drastically improved a doctor's ability to diagnose tuberculosis. Percy had to undergo special training in order to guarantee the smooth running of the machine, also in case of defects. ${ }^{216}$ As of 1965 , the X-Ray room was the only room equipped with air-conditioning. ${ }^{217}$ In the kitchen, petroleum-driven refrigerators were still in use. As their spark plugs were susceptible to failure and had to be exchanged several times a week, nurses who worked in the kitchen acquired some of the basic skills needed to fix them. ${ }^{218}$ Because refrigeration was limited, a considerable quantity of drugs was stored in basements where they were protected from the sun.

A large number of these drugs, and other objects, had to be thrown away, because they were either badly packed and did not endure the heat and humidity or were invaded by ants. ${ }^{219}$ Jacques Boucah, whose mother would work in the maternity ward, arrived at the hospital in 1956 at the age of nine years. One of his summer jobs was to identify and burn pharmaceuticals that had expired or spoiled. ${ }^{220}$ Gerald McKnight, one of the hospital's first and most well-known critics, argued that no one at the institution could keep track of the incoming supply of drugs and suspected that pharmaceutical companies were using it as a dumping ground. ${ }^{221}$ We do know, however, that doctors, together with some nurses, were responsible for ordering medication and must therefore have had at least some idea of what was missing. ${ }^{22}$ Some medications were also produced on site, including all saline solutions. ${ }^{223}$ Also to be found in the basements, occupying valuable storage space, were a large variety of objects with little practical value, from ties to pepper casters, which had been donated from overseas. ${ }^{224}$ In order not to upset Schweitzer, employees secretly disposed of some of these items by burying them or throwing them

216 For a detailed discussion on the acquirement of the X-ray equipment, see: Mabika Ognandzi, Steinke, and Zumthurm, Schweitzer's Lambaréné: A Hospital in Colonial Africa.

217 According to Walter Munz, Dr. Rolf Müller found this air-conditioning unit in a basement. They both assumed that Ali Silver had stored it there without informing anyone else after it had been donated to the hospital. Arguably, Silver shared Schweitzer's distaste of new machinery. See: Interview Munz and Munz.

218 Füllemann, 'Aus jüngster Zeit', 163; Group Interview Speicherschwendi.

219 Cousins, Dr. Schweitzer of Lambaréné, 103.

220 Interview Jacques Boucah.

221 Gerald McKnight, Verdict on Schweitzer, 35 f.

222 Interview Elisabeth Anderegg; Interview Hedwig Schnee.

223 Interview Marianne Stocker; Interview Hedwig Schnee.

224 Group Interview; Stocker, 'Diary 1961-63', 16. 
into the river. ${ }^{225}$ These accounts convey an image of abundance that differs from the typical one of a colonial health facility that is in constant shortage of supplies.

When Norman Cousins toured the hospital in early 1957, he noted that 'the sanitary facilities were at an absolute minimum. There were only two outhouses, one for each sex'.226 European staff, for whose use they were reserved, detested the place and referred to it as 'Hinter-India., ${ }^{227}$ There were no sanitary facilities whatsoever for African patients. They were thus forced to relieve themselves in the open, the river being a preferred location. ${ }^{228}$ Two showers, each in reality a bucket with holes attached to a rope, were located in a hut next to the dining room; only European staff knew where to find the keys. ${ }^{229}$ Padlocks were a feature throughout the hospital, especially in the kitchen. ${ }^{230}$ There was, like in the surrounding region, a widespread fear of theft, including among Africans. ${ }^{231}$

Another feature that added to the hospital's insanitary appearance were the free-roaming animals. In 1924, Kottmann wrote of two goats as well as some chickens that refused to lay eggs. ${ }^{232}$ In 1933, Schweitzer claimed that 20 percent of the hospital's required milk came from its own goats. ${ }^{233}$ In the early 196os, goats were reportedly entering the Grande Pharmacie. ${ }^{234}$ In addition to this subsistence livestock, a great variety of animals lived freely on the hospital grounds. A pelican, for example, gained considerable fame when Schweitzer published a whole book written from its perspective in $1950 .{ }^{235}$

225 Interview Ursula Bunch.

226 Cousins, Dr. Schweitzer of Lambaréné, 92.

227 Interview Hedwig Schnee; Interview Munz and Munz.

228 A remark made by numerous observers; see, for example: Cousins, Dr. Schweitzer of Lambaréné, 71; Fernandez, 'The Sound of Bells in a Christian Country', 544; Emane, Docteur Schweitzer: une icône africaine, 97.

229 Stocker, 'Diary 1961-63', 33; Interview Ursula Bunch.

230 Fernandez, 'The Sound of Bells in a Christian Country', 544; Oermann, Albert Schweitzer $1875^{-1965,250 .}$

231 Intrerview Ursula Bunch; Stocker, 'Diary 1961-63', 12. See also: Arnold, 'Vous les noirs, nous les blancs', 433. Arnold claims that fetishes protecting against theft were very common in the region. Fernandez underlines that for the Fang, 'thievery is one of the greatest evils, for it is an obvious and direct threat to the integrity of each social unit'; Fernandez, 'Christian Acculturation and Fang Witchcraft', 250.

232 Schweitzer, 'Neues von Albert Schweitzer Oktober 1924', 7. For a more detailed discussion about the role of animals at the hospital, see: Mabika Ognandzi, Steinke, and Zumthurm, Schweitzer's Lambaréné: A Hospital in Colonial Africa.

233 Schweitzer, 'Briefe aus dem Lambarene Spital Juli 1933', 7.

234 Interview Hedwig Schnee.

235 Albert Schweitzer, Richard Meiner, Ein Pelikan Erzählt Aus Seinem Leben. 
Stories of nurses raising gorillas or chimpanzees abound. ${ }^{236}$ In 1961, Stocker wrote in her diary that she was the only nurse who did not have a pet to look after in her room and complained of dogs entering the consultation rooms. ${ }^{237}$ During the early 1960s, rats were considered such a pest that the legs of the tables in the kitchen were placed in buckets of kerosene in an attempt to keep the rodents away from edibles. ${ }^{238}$

While they acknowledged at least some of these shortcomings, the overwhelming majority of former staff whom I interviewed believed that the basic medical care provided at the hospital was of a high standard. ${ }^{239}$ This is an opinion shared by many visitors. ${ }^{240}$ In the latest biography of Schweitzer, Nils Ole Oermann comes to a similar conclusion. To further support this argument, he points to the fact that many Europeans preferred to be treated at Schweitzer's hospital than at the government clinic. ${ }^{241}$ Jacques Bessuges, the colonial government physician in Lambaréné during the early 1950s, offers a different interpretation. He claims that some European residents in Gabon favored Schweitzer's hospital as a result of its glamorous atmosphere and because it looked impressive as a place of birth on their child's birth certificate. According to Bessuges, they were less positive about the conditions that they found there. He reports that one patient had exclaimed: 'What is so extraordinary about this Doctor Schweitzer? What a hospital, his hospital! It is shameful!'242 Bessuges maintained good relations with Schweitzer, as we will see in Chapter 2. Indeed, his overall assessment of the level of service and the conditions at the hospital was not overly negative. In the hospital's defense, he contended that, considering the difficult circumstances in which it operated, it was not particularly unhygienic. He also sensed that staff and patients were happy there, whereas he complained about the depressing atmosphere and filth of his own workplace. ${ }^{243}$

236 Haussknecht, Emma Haussknecht, 1895-1956, 64; Sixt, 'Krankenschwester bei Albert Schweitzer', 62; Group Interview Speicherschwendi.

237 Stocker, 'Diary 1961-63', 17.

238 Group Interview Speicherschwendi. Schweitzer mentioned a rat problem already in 1937. In: 'Briefe aus dem Lambarene-Spital Mai 1937', 6.

239 Interview Munz and Munz; Group Interview Speicherschwendi; Interview Ursula Bunch; Interview Elisabeth Anderegg.

240 Cousins cites Dr. Cyrille Coulon, who, having worked as an itinerant doctor in South Africa, was impressed by the equipment that he found in Lambaréné in 1956. See: Cousins, Dr. Schweitzer of Lambaréné, 138. Dr. Lavdris Christensen concurred some two years later, adding that local conditions could and should not be compared with those of contemporary European hospitals. See: Østergaard Christensen, At Work with Albert Schweitzer, 66.

241 Oermann, Albert Schweitzer 1875-1965, 243-53.

242 Bessuges, Lambaréné à l'ombre de Schweitzer, 125.

243 Ibid., 54, 72, 125-26. 
The presence of animals on the grounds of colonial hospitals was not unprecedented. ${ }^{244}$ Backwardness and insalubrity were regular criticisms leveled against many healthcare institutions in various colonies. ${ }^{245}$ This is not surprising given that hygiene was so central to the discourses of most colonial missionaries and physicians alike. ${ }^{246}$ However, accusations against Schweitzer and his hospital were and remain especially persistent.

Colonial hospitals' access to equipment varied greatly, both within colonies and across the colonial world. For example, the first X-Ray equipment in what is today Malawi was installed in 1927 at the Livingstonia Medical Mission, but other mission hospitals in the same colony never acquired one. ${ }^{247}$ The mission hospital at Agogo in colonial Ghana meanwhile, had acquired a radiography machine by $1938 .{ }^{248}$ Schweitzer thus acquired his own radiography equipment comparatively late, but missions in India, for instance, received theirs even later. ${ }^{249} \mathrm{~A}$ similar point can be made for electricity. In 1924, Chesterman wrote to Schweitzer from Yakusu in the Belgian Congo, reporting that he had equipped the whole hospital with electric lights. ${ }^{250}$ In contrast, the general government hospital in Brazzaville did not acquire electricity in the $1920{ }^{251}$ Similarly, the government hospital in Libreville, for which electric equipment was planned for 1933, had to wait at least a further two years before being electrified. ${ }^{252} \mathrm{Ga}-$ bon's second most important city, Port-Gentil, and its hospital were only electrified in 1950, almost ten years after Schweitzer had electrified sections of the Grande Pharmacie. 253

The reasons why any hospital might be equipped with comparatively few technologies were often economic, especially in the colonies, as Joel D. Howell reminds us. He also insists that, at the same time, cultural factors should not be

244 Hardiman, Missionaries and Their Medicine, 204; Headrick, Colonialism, Health and Illness in French Equatorial Africa, 195-96.

245 Eckart, Medizin und Kolonialimperialismus, 543; Kalusa, 'Christian Medical Discourse and Praxis on the Imperial Frontier', 256; Patterson, Health in Colonial Ghana, 19.

246 Bruchhausen, 'Practising Hygiene and Fighting the Natives' Diseases'; Lachenal, 'Le médecin qui voulut être roi', 139-40; Ombongi, 'The Historical Interface between the State and Medical Science in Africa', 356; Ratschiller, 'Kranke Körper'.

247 Good, The Steamer Parish, 402.

248 Schmid, 'Mission Medicine in a Decolonising Health Care System', 295.

249 Hardiman, Missionaries and Their Medicine, 209.

250 Chesterman to Schweitzer, 2 November 1924, AMs.

251 Headrick, Colonialism, Health and Illness in French Equatorial Africa, 194-97. It is not clear from the book precisely when Brazzaville's hospital was electrified.

252 See the Conclusion in: 'Rapport Annuel du Service de Santé de la Colonie Du Gabon 1932'. ZK 005-127, SHD. No references to electricity could be found in the 1933 and 1934 annual reports. Subsequent reports are missing.

253 Mabika, 'Médicalisation de l'Afrique centrale', 224. No information on the electrification of the government hospitals in Libreville or Lambaréné could be found. 
neglected, positing that 'the belief that excellence in health care is machinedependent may be less important in some parts of the world. ${ }^{254}$ For South African hospitals, Anne Digby concludes that in the period from 1930 to $195^{\circ}$, superior healing rates do not necessarily correlate with better or more modern facilities, or even a high standard of clinical care. Her case studies suggest that patients' attitudes and the geographical accessibility of healthcare institutions are significantly more important. ${ }^{255}$ Terrence Ranger has observed this tension in the case of Tanzania, where it was widely acknowledged by the 1930s that 'mission medicine had not been triumphant after all'; in response, whereas the European clergy proposed simpler forms of treatment, medical personnel pressed for modernization. ${ }^{256}$

Schweitzer seems to have followed the logic of the theological personnel of missions, refusing to modernize his hospital on a large scale. However, he did not share the common missionary approach to medicine that often targeted

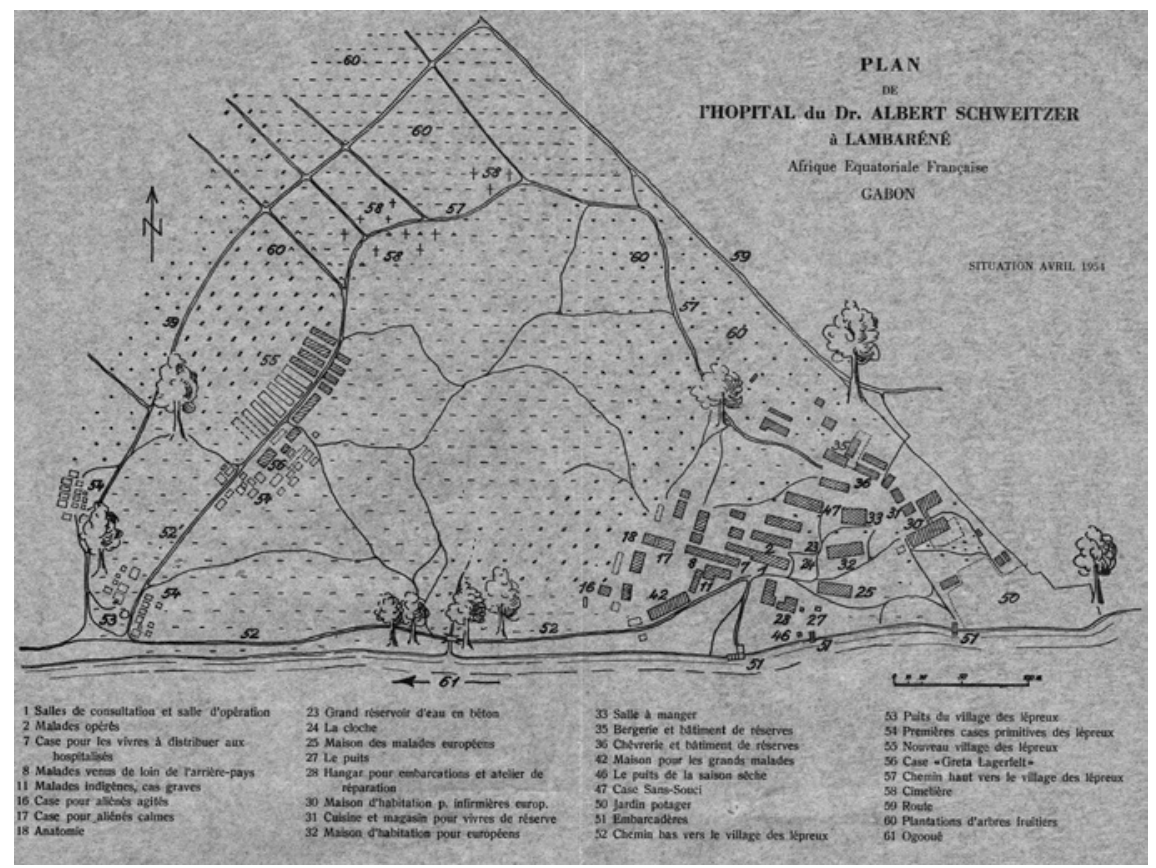

MAP 4 A plan of the hospital in 1954, taken from the 'Lettres de l'Hôpital du Dr. Albert Schweitzer à Lambaréné' (No. 14, 1954)

254 Howell, 'Hospitals', 513.

255 Digby, Diversity and Division in Medicine, 127.

256 Ranger, 'Godly Medicine', $273-74$. 
the community at large and aimed at transforming it. Schweitzer's ideology in this respect resembled that of biomedical practitioners, with their strong focus on the individual. Having said that, it has to be mentioned that this distinction was never unequivocal, and much of the work that missionary doctors undertook was targeted at the individual, not at the wider community. ${ }^{257}$ Schweitzer believed that the medical services offered by his hospital (Map 4) were simply that: a service that any individual reaching for it would receive. ${ }^{258}$

\section{$9 \quad$ Conclusion}

When highlighting changes and continuities at the Albert Schweitzer Hospital in Lambaréné, the most obvious development was the institution's growth in all respects: in 1965, it had more patients, more doctors, more nurses, more auxiliaries, and more buildings than thirty years earlier. The most significant changes only occurred in the late 1950s, probably the result of new political dynamics in many areas of public service shortly before Gabonese independence, including in the health sector.

In reconstructing the routines of hospital life interviews were particularly valuable, as interviewees often recalled them in vivid detail. Interviews were less fruitful for recapitulating specific medical practices, as we will see in the following chapters, which rely more heavily on written sources. Furthermore, interviews were crucial in illuminating differences of opinion between Africans and Europeans, such as on the question of payment for treatment or on that of the training of local staff.

Schweitzer envisaged his hospital as a highly ordered space in which all staff had a specific role to play. On closer examination, however, his management style was very pragmatic. Doctors, nurses and auxiliaries were all required to switch between responsibilities throughout their stay and be highly flexible in the execution of their daily duties. On the other hand, a strong hierarchy prevailed; moreover, all staff had to adhere to a normative set of values, the 'Lambaréné Spirit'. Their willingness to do so as well as their personal contacts within Schweitzer's vast transcontinental network of supporters were decisive factors in whether potential personnel were hired.

Until the Great Depression, the vast majority of patients also made their way to the hospital via a network in its own right, the web of lumber camps

257 Jennings, 'Healing of Bodies, Salvation of Souls'.

$25^{8}$ This argument is further developed in: Mabika Ognandzi, Steinke, and Zumthurm, Schweitzer's Lambaréné: a Hospital in Colonial Africa. 
in the surrounding region. After 1931, patients' origins diversified, but loggers remained a well-represented group. All patients were permitted, indeed expected, to bring gardiens, who were to provide basic care for their ill companions and contribute their labor to the hospital. This practice also occurred at other hospitals on the continent and was consistent with wider healing practices in the region. The Albert Schweitzer Hospital was successful in carving out a role for itself in this pluralist setting. Once there, patients had to follow a seemingly set and ordered routine that was, in reality, implemented in a more pragmatic manner. However, patients still had to submit to constant supervision in many aspects of their lives. 